Article

\title{
Kinetics Study of Al Extraction from Desilicated Coal Fly Ash by $\mathrm{NaOH}$ at Atmospheric Pressure
}

\author{
Andrei Shoppert ${ }^{1, * \mathbb{C}}$, Irina Loginova ${ }^{1}$ and Dmitry Valeev ${ }^{2}(\mathbb{D}$ \\ 1 Department of Non-Ferrous Metals Metallurgy, Ural Federal University, 620002 Yekaterinburg, Russia; \\ loginova_irina@mail.ru \\ 2 Laboratory of Sorption Methods, Vernadsky Institute of Geochemistry and Analytical Chemistry of the \\ Russian Academy of Sciences, 119991 Moscow, Russia; dmvaleev@yandex.ru \\ * Correspondence: a.a.shoppert@urfu.ru
}

check for updates

Citation: Shoppert, A.; Loginova, I.; Valeev, D. Kinetics Study of Al Extraction from Desilicated Coal Fly Ash by $\mathrm{NaOH}$ at Atmospheric Pressure. Materials 2021, 14, 7700. https://doi.org/10.3390/ma14247700

Academic Editor: Carlos

Manuel Silva

Received: 1 November 2021

Accepted: 11 December 2021

Published: 13 December 2021

Publisher's Note: MDPI stays neutral with regard to jurisdictional claims in published maps and institutional affiliations.

Copyright: (C) 2021 by the authors. Licensee MDPI, Basel, Switzerland. This article is an open access article distributed under the terms and conditions of the Creative Commons Attribution (CC BY) license (https:/ / creativecommons.org/licenses/by/ $4.0 /)$.
Abstract: The most promising source of alumina in the 21st century is the coal fly ash (CFA) waste of coal-fired thermal plants. The methods of alumina extraction from CFA are often based on the pressure alkaline or acid leaching or preliminary roasting with different additives followed by water leaching. The efficiency of the alumina extraction from CFA under atmospheric pressure leaching is low due to the high content of acid-insoluble alumina phase mullite $\left(3 \mathrm{Al}_{2} \mathrm{O}_{3} \cdot 2 \mathrm{SiO}_{2}\right)$. This research for the first time shows the possibility of mullite leaching under atmospheric pressure after preliminary desilication using high liquid to solid ratios (L:S ratio) and $\mathrm{Na}_{2} \mathrm{O}$ concentration. The analysis of the desilicated CFA (DCFA) chemical and phase composition before and after leaching has been carried out by inductively coupled plasma optical emission spectrometry (ICP-OES) and X-ray diffraction (XRD). The morphology and elemental composition of solid product particles has been carried out by scanning electron microscopy with energy-dispersive X-ray spectroscopy (SEM-EDX). An automated neural network and a shrinking core model (SCM) were used to evaluate experimental data. The $\mathrm{Al}$ extraction efficiency from DCFA has been more than $84 \%$ at $\mathrm{T}=120^{\circ} \mathrm{C}$, leaching time $60 \mathrm{~min}$, the $\mathrm{L} / \mathrm{S}$ ratio $>20$, and concentration of $\mathrm{Na}_{2} \mathrm{O}-400 \mathrm{~g} \mathrm{~L}^{-1}$. The kinetics analysis by SCM has shown that the surface chemical reaction controls the leaching process rate at $\mathrm{T}<110{ }^{\circ} \mathrm{C}$, and, at $\mathrm{T}>110^{\circ} \mathrm{C}$ after $15 \mathrm{~min}$ of leaching, the process is limited by diffusion through the product layer, which can be represented by titanium compounds. According to the SEM-EDX analysis of the solid residue, the magnetite spheres and mullite acicular particles were the main phases that remained after $\mathrm{NaOH}$ leaching. The spheric agglomerates of mullite particles with non-porous surface have also been found.

Keywords: mullite; coal fly ash; alkaline; leaching; neural network; machine learning; kinetics; shrinking core model

\section{Introduction}

Two types of ash are produced during coal combustion in boilers: coal bottom ash (CBA) and collected in the waste gas system coal fly ash (CFA), which together are called the coal ash (CA). The chemical and phase composition of the CA depends on many factors, including the coal deposit, coal combustion methods and parameters, etc. [1]. There are two types of ash that are obtained by different combustion methods [2]: in pulverized coal boilers and using a circulating fluidized bed. CA from the fluidized bed boilers is formed at a lower temperature $\left(850-950{ }^{\circ} \mathrm{C}\right)$, does not have microsphere particles, and the main phase of alumina is amorphous glassy mass. CA from the pulverized coal boilers formed during the melting of coal mineral inclusions of coal at $\mathrm{T}=1200-1500{ }^{\circ} \mathrm{C}$. Thus, the main alumina phase in such CA is mullite represented by spherical particles.

CFA contains many valuable components, primarily alumina and silica. The alumina content in some types of ash can be comparable to bauxite; this ash is called high alumina fly ash (HAFA). The Inner Mongolia Autonomous Region (China) provides a special type 
of coal; after the combustion process, it generates ash with a high alumina content, up to $50 \%$ [3]. HAFA is a promising raw material for alumina production [4] due to the limited reserves of bauxite located in China [5]. However, alumina content in the typical ash is about $25-30 \%$ [6], while silica is more than $50 \%$.

Many hydrometallurgical methods of alumina extraction from CFA have been developed to date. They can be divided into alkaline [7-9], acidic [10-13], and roasting (combined pyro- and hydrometallurgical) [14-20], when the roasting product is leached by water or mineral acids.

Roasting methods are based on the conversion of aluminum from insoluble minerals into water-soluble ones during its reaction with different additives $(\mathrm{NaOH}$ [21], $\mathrm{Na}_{2} \mathrm{CO}_{3}$ [22], $\mathrm{NaCl}$ [23], $\mathrm{CaCO}_{3}$ [24], $\mathrm{CaCl}_{2}$ [25] at $\mathrm{T}=400-1200{ }^{\circ} \mathrm{C}$ ). Aluminum can be extracted from CFA after roasting by acid leaching at atmospheric pressure $[17,26]$. The roasting flux dissolves into the solution and cannot be reused. So, these methods require higher energy and reagents consumption and are less environmentally friendly compared to hydrometallurgical methods.

Acidic methods allow a selective $\mathrm{Al}$ extraction from CFA by $\mathrm{HCl}[23,27], \mathrm{H}_{2} \mathrm{SO}_{4}$ [28], and $\mathrm{NH}_{4} \mathrm{HSO}_{4}$ [29] using high-pressure reactors. However, CFA leaching at atmospheric pressure leads to a low $\mathrm{Al}$ extraction degree [4]. It was found that the process can be intensified by hydrofluoric acid (HF) addition [30] or using a combination of acid and alkaline leaching, but equipment with high corrosion resistance is required.

Alkaline methods used for the $\mathrm{Al}$ extraction from bauxite are less efficient for CFA [31]. This is due to the fact that CFA contains a high amount of amorphous glassy silica, which dissolves faster than Al-containing minerals [32]. The presence of $\mathrm{SiO}_{3}{ }^{2-}$ in solution simultaneously with $\mathrm{NaAlO}_{2}{ }^{-}$leads to the precipitation of desilication product (DSP, $\mathrm{Na}_{6}\left[\mathrm{Al}_{6} \mathrm{Si}_{6} \mathrm{O}_{24}\right] \mathrm{Na}_{2} \mathrm{X}$ (where $\mathrm{X}$ is different inorganic anions) [33]. A large amount of $\mathrm{Al}$ and $\mathrm{Na}$ are lost with the DSP. The silica content in the CFA can be reduced by the preliminary alkali desilication. Simultaneously, the alumina content in the solid residue increases from $20-30 \%$ to $30-50 \%$. After the CFA alkali desilication process, the pure solutions of sodium silicate $\left(\mathrm{Na}_{2} \mathrm{SiO}_{3}\right)$ are obtained. Silica solution after CFA desilication is used for mesoporous silica nanoparticles or various types of zeolites production [5,34-39].

However, using the conventional desilication method at the low L:S ratio, the $\mathrm{Si}$ extraction at the preliminary alkaline desilication stage does not exceed $60 \%$; as much as $\approx 12-14$ wt. $\% \mathrm{Na}_{2} \mathrm{O}$ was found in the solid residue after desilication [40]. This is because a part of alumina in the CFA is contained in an amorphous glassy mass that readily dissolves and leads to DSP precipitation. To reduce the alkali losses during the desilication process, Aphane M. et al. suggested leaching of a readily soluble $\mathrm{Al}$ from the glass mass by acid [41].

Further Al extraction from desilicated CFA is carried out in high-pressure reactors [42], since most of the $\mathrm{Al}$ is contained in the CFA in refractory mullite $\left(3 \mathrm{Al}_{2} \mathrm{O}_{3} \cdot 2 \mathrm{SiO}_{2}\right)$. The low $\mathrm{Al}$ extraction degree from mullite can be also related to solid films of amorphous glassy mass and DSP on the CFA surface [4]. Using hydrothermal conditions at T $>250{ }^{\circ} \mathrm{C}$ in the presence of a certain amount of lime, it is possible to extract more than $90 \%$ of $\mathrm{Al}$ by obtaining DSP with a low Al and Na content [43]. Therefore, the DSP formation is an important issue for $\mathrm{Al}$ extraction from CFA by alkaline methods, and the development of new methods for $\mathrm{Si}$ and $\mathrm{Al}$ extraction from $\mathrm{CFA}$ by $\mathrm{NaOH}$ is required.

Our previous study showed that it is possible to completely remove the amorphous glassy mass from the CFA without the DSP formation during alkaline desilication at the high liquid to solid (L/S) ratio and $\mathrm{Na}_{2} \mathrm{O}$ concentration [32]. This fact is associated with the retention of silica in the metastable area $[44,45]$ that helps to extract more than $90 \%$ of $\mathrm{Si}$ with minimal alkali losses. At the high leaching duration and temperature $\left(>110^{\circ} \mathrm{C}\right)$, it was found that, in addition to amorphous glassy mass, mullite begin to dissolve at the atmospheric pressure. The purpose of this study is to evaluate the $\mathrm{Al}$ extraction by a concentrated $\mathrm{NaOH}$ solution at atmospheric pressure from the desilicated by the new method CFA. The kinetics and mechanism of the mullite leaching have been studied. 


\section{Materials and Methods}

\subsection{Materials and Reagents}

DCFA obtained by the desilication of the coal fly ash from the Reftinskaya thermal power plant in Asbest, Russia (GPS coordinates: 57.112213, 61.704545) was used as a raw material. The desilication process was carried out at $\mathrm{T}=120^{\circ} \mathrm{C}, \mathrm{L}: \mathrm{S}=20$, leaching time $20 \mathrm{~min}$, and $400 \mathrm{~g} \mathrm{~L}^{-1}$ of $\mathrm{Na}_{2} \mathrm{O}$ [32]. Caustic alkali (JSC Soda, Sterlitamak, Russia) and aluminum hydroxide $\left(\mathrm{Al}(\mathrm{OH})_{3}\right)$ (JSC "BaselCement-Pikalevo", Pikalevo, Russia) of the analytical grade were used in the present research. The alkaline solutions were prepared by dissolving a predetermined amount of the solid $\mathrm{NaOH}$ in $300 \mathrm{~mL}$ of distilled water. After complete dissolution, the volume was adjusted by water to obtain a solution with the $\mathrm{Na}_{2} \mathrm{O}$ concentration of 330,360 , or $400 \mathrm{~g} \mathrm{~L}^{-1}$ ( $\mathrm{C}_{\mathrm{Na} 2 \mathrm{O}}$ ). To study the effect of the $\mathrm{Al}$ concentration in the solution on the leaching process, solutions of various initial concentrations-190 and $380 \mathrm{~g} \mathrm{~L}^{-1} \mathrm{Al}_{2} \mathrm{O}_{3}\left(\mathrm{C}_{\mathrm{Al2} 23}{ }^{0}\right)$ were prepared by dissolving the $\mathrm{Al}(\mathrm{OH})_{3}$ in a hot alkaline solution.

\subsection{Analysis}

The mineral composition of the solid samples was determined by X-ray diffraction (XRD) using a Difrei-401 diffractometer (JSC Scientific Instruments, Saint Petersburg, Russia) using a $\mathrm{Cr}-\mathrm{K} \alpha$ radiator with $2 \theta$ angles ranging from $15^{\circ}$ to $140^{\circ}$. The operating mode of the X-ray source was $25 \mathrm{~kW} / 4 \mathrm{~mA}$ with $30 \mathrm{~min}$ of exposure time. Match 3 software was used to process the diffraction data. The quantitative analysis of crystalline phases in the DCFA sample was carried out by the Rietveld quantitative phase analysis (RQPA) method, using "FullProf" and "Match! 3" software (Crystal impact, Bonn, Germany) for analysis.

Chemical analysis was performed after complete dissolution of the solid residue by a mixture of concentrated hydrofluoric, sulfuric, and nitric acids; the residue was subsequently fused with soda and boric acid at $950{ }^{\circ} \mathrm{C}$ and leached using $1 \mathrm{~N} \mathrm{HCl}$ solution, which was followed by inductively coupled plasma optical emission spectrometry (ICP-OES) analysis, using a spectrometer Vista Pro (Varian Optical Spectroscopy Instr., Mulgrave, Australia). For quality assurance, samples were analyzed twice. The carbon contents analysis was performed via a fractional gas analyzer CS-600 (LECO Corporation, St. Joseph, MI, USA). The loss on ignition (LOI) was determined by calcination at $1000{ }^{\circ} \mathrm{C}$ for $60 \mathrm{~min}$.

The morphological forms and the elemental composition of the main minerals of the samples were determined by means of scanning electron microscopy with energy-dispersive X-ray spectroscopy (SEM-EDX, Vega III, Tescan, Brno, Czech Republic). In order to reduce the charge formed on the surface, a current-conducting coating was applied to the surface of the samples via a Q150R ES coater (Quorum Technologies, UK). The coating was applied by cathode sputtering; the materials of the coating were gold (to determine the spatial location of the particles) and carbon (to determine the structure of the samples and perform X-ray microanalysis.

The particle size distribution and mean particle size analysis were performed by the laser diffraction method (LD) using an Analysette 22 NanoTec (Fritsch, Idar-Oberstein, Germany). The specific surface area of the samples was determined via the BrunauerEmmett-Teller method (BET) using NOVA 1200e (Quantachrome Instruments, Boynton Beach, FL, USA). Before BET analysis, all samples were subjected to degassing under vacuum at $200{ }^{\circ} \mathrm{C}$ for $12 \mathrm{~h}$.

\subsection{Experiments}

Preliminary desilication of CFA and DCFA leaching by $\mathrm{NaOH}$ was carried out in the thermostated $0.5 \mathrm{~L}$ stainless steel reactor (Figure 1). The reactor has openings for injecting chemical reagents as well as for temperature control and the recycling of evaporated water through a water-cooled condenser. The stirring speed in all experiments was $400 \mathrm{rpm}$ : previously [32], it was found that leaching efficiency does not improve at a higher rotation speed. The DCFA was added to the solution with the $\mathrm{Na}_{2} \mathrm{O}$ concentration of 330,360 , or 
$400 \mathrm{~g} \mathrm{~L}^{-1}$ and an initial concentration of $\mathrm{Al}_{2} \mathrm{O}_{3}$ 0, 190, and $380 \mathrm{~g} \mathrm{~L}^{-1}$. After leaching, the pulp was filtered; the solid residue was dried at $110{ }^{\circ} \mathrm{C}$ for $240 \mathrm{~min}$ before analysis using ICP-OES.

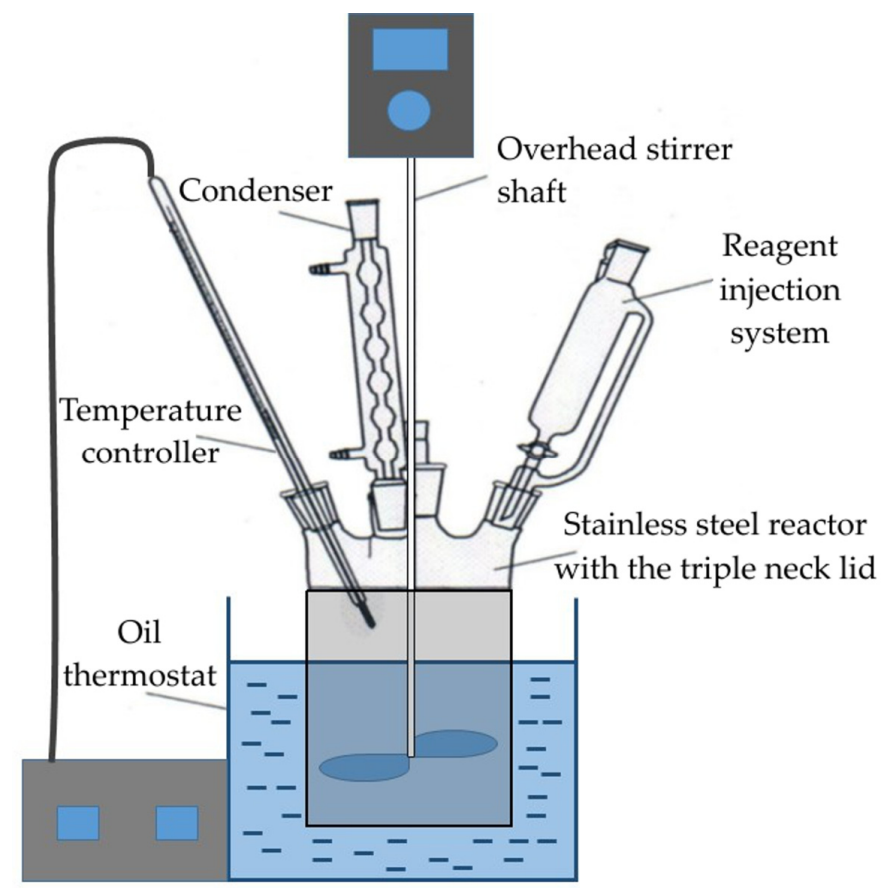

Figure 1. Schematic of the $\mathrm{NaOH}$ leaching experimental set-up.

\subsection{Experimental Data Evaluation}

The extraction degree of $\mathrm{Al}$ and $\mathrm{Si}$ from DCFA after $\mathrm{NaOH}$ leaching was calculated by Equation (1):

$$
\alpha=\left[\left(\mathrm{m}_{1} \times \mathrm{Me}_{1}\right) /\left(\mathrm{m}_{2} \times \mathrm{Me}_{2}\right)\right] \times 100 \%,
$$

where $\mathrm{Me}_{1}$ is the $\mathrm{Al}$ or Si content in the solid residue obtained after DCFA leaching by $\mathrm{NaOH}, \% ; \mathrm{m}_{1}$ is the weight of the solid residue; $\mathrm{Me}_{2}$ is the content of the $\mathrm{Al}$ or $\mathrm{Si}$ in the DCFA, \%; $m_{2}$ is the weight of the DCFA load in the experiment, $g$.

Statistical-based automated neural network (SANN) was used for modeling of DCFA leaching by $\mathrm{NaOH}$. SANN is an artificial intelligent method that adjusts the result of modelling until the desired quality is obtained. "STATISTICA 13" software was used for SANN modelling via a multilayer perceptron (MLP) method. MLP implies the creation of a neural network consisting of input, hidden, and output layers, where hidden and output layers are the activation function that is executed progressively to obtain an output value depending on the input parameters. The input parameters were the leaching duration $(\tau, \mathrm{min})$, the $\mathrm{L}: \mathrm{S}$ ratio $(\mathrm{L}: \mathrm{S})$, the temperature $\left(\mathrm{T},{ }^{\circ} \mathrm{C}\right), \mathrm{Na}_{2} \mathrm{O}$ concentration $\left(\mathrm{C}_{\mathrm{Na} 2 \mathrm{O}}, \mathrm{g} \mathrm{L}^{-1}\right)$, initial $\mathrm{Al}_{2} \mathrm{O}_{3}$ concentration $\left(\mathrm{C}_{\mathrm{Al} 2 \mathrm{O}}{ }^{0}, \mathrm{~g} \mathrm{~L}^{-1}\right)$, and the initial mean particle size $\left(\mathrm{r}^{0}, \mu \mathrm{m}\right)$. The output layer consisted of one response variable: extraction of $\mathrm{Al}$ (wt. \%). MLP was set to a minimum of 3 hidden layers and a maximum of 10 hidden layers. The number of networks to train was 50, and the networks to save was 5 . Other parameters were automated by the software. The SANN modeling process implies that the matrix structure is not needed.

The kinetic parameters and the coefficients of determination were calculated using "non-linear curve fit analysis" in commercial software, which is based on the non-linear least-squares method. This method reduces the number of calculations and figures. The main advantage of this method is the possibility to evaluate the quality of fitting experimental data by the non-linear chi-square test $(x 2)$ [46]. The different SCM models were manually added as an "explicit function". "Independent variable" was the time of leaching, "Dependent variable" was the fraction of reacted solid or the degree of conversion; "parameters" was the apparent rate constant. 


\section{Results and Discussion}

\subsection{Characterization of the Raw CFA and DCFA}

The raw CFA was desilicated at the parameters that exclude high losses of $\mathrm{Al}$ due to mullite dissolution (leaching time $<20 \mathrm{~min}$ ); i.e., it is suggested that during the desilication stage, only amorphous glassy mass was extracted. The yield of DCFA was $40.5 \mathrm{wt}$. \% of the raw CFA sample mass. The $\mathrm{Al}$ and $\mathrm{Si}$ extraction at the desilication stage were 17.3 and $80.7 \mathrm{wt}$. \%, respectively. The particle size distribution of the CFA, DCFA, and the solid residue after mullite leaching is shown in Figure 2. DCFA used in the kinetic study was subjected to a sieve analysis to obtain three fractions: $-50 \mu \mathrm{m},+50-71 \mu \mathrm{m}$, and $+71 \mu \mathrm{m}$. The average particle size of each fraction was: $48 \mu \mathrm{m}, 62 \mu \mathrm{m}$, and $87 \mu \mathrm{m}$. The chemical composition of these three fractions and the raw CFA is shown in Table 1.

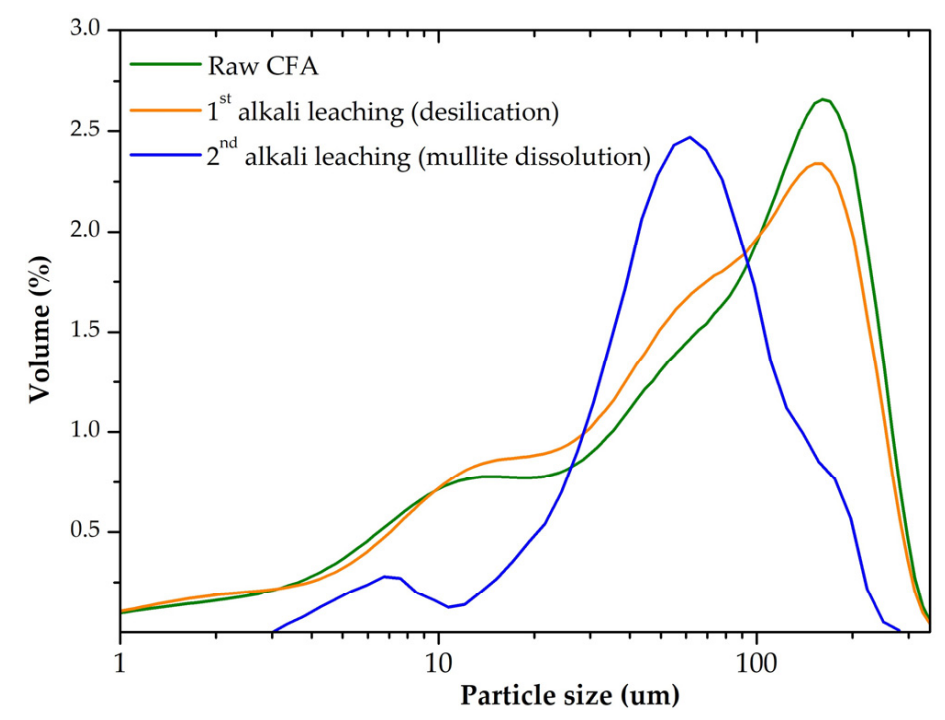

Figure 2. The particle size distribution of the raw coal fly ash (CFA, green curve), desilicated CFA (DCFA, orange curve), and DCFA after $\mathrm{NaOH}$ leaching at $\mathrm{T}=120^{\circ} \mathrm{C}$, L:S ratio $=20, \tau=60 \mathrm{~min}$ (blue curve).

Table 1. Chemical composition of the raw CFA and DCFA three size fractions: $-50 \mu \mathrm{m},+50-74 \mu \mathrm{m}$, and $+74 \mu \mathrm{m}$.

\begin{tabular}{|c|c|c|c|c|c|c|c|c|c|c|}
\hline \multirow{2}{*}{ Size Fraction } & \multicolumn{10}{|c|}{ Main Components, wt. \% } \\
\hline & $\mathrm{SiO}_{2}$ & $\mathrm{Al}_{2} \mathrm{O}_{3}$ & $\mathrm{CaO}$ & $\mathrm{Fe}_{2} \mathrm{O}_{3}$ & $\mathrm{TiO}_{2}$ & $\mathrm{MgO}$ & $\mathrm{Na}_{2} \mathrm{O}$ & $\mathrm{K}_{2} \mathrm{O}$ & LOI & $\mathrm{C}$ \\
\hline Raw CFA & 62.94 & 23.98 & 1.59 & 3.45 & 1.11 & 0.43 & 0.72 & 0.93 & 3.99 & 1.60 \\
\hline$-50 \mu \mathrm{m}$ & 33.44 & 47.58 & 2.98 & 8.65 & 1.96 & 0.59 & 0.63 & 0.15 & 4.01 & 3.29 \\
\hline$+50-71 \mu \mathrm{m}$ & 33.51 & 47.70 & 2.97 & 8.45 & 1.85 & 0.57 & 0.62 & 0.17 & 4.10 & 3.75 \\
\hline$+71 \mu \mathrm{m}$ & 34.51 & 46.10 & 2.97 & 6.39 & 1.50 & 0.46 & 1.18 & 0.18 & 6.51 & 5.05 \\
\hline
\end{tabular}

Figure 3 shows the XRD pattern of the raw CFA and DCFA. The DCFA mainly consists of three mineral phases: mullite, magnetite $\left(\mathrm{Fe}_{3} \mathrm{O}_{4}\right)$, and quartz $\left(\mathrm{SiO}_{2}\right)$. A glassy amorphous phase (from $20^{\circ}$ to $50^{\circ}$ 2Theta) the raw CFA was eliminated by alkali leaching at the desilication stage. Therefore, the remaining $82.7 \%$ of $\mathrm{Al}$ and $19.3 \%$ of $\mathrm{Si}$ from the raw CFA are mainly contained in mullite and quartz, which was confirmed by the Rietveld method. The quantitative analysis of crystalline phases in the DCFA sample is shown in Table 2. According to Table 2, more than 78\% of DCFA is represented by mullite. However, it should be noted that unburned coal and other aluminosilicates are X-ray amorphous.

The effect of the raw CFA desilication on the morphology and the chemical composition of the particles was evaluated using the SEM-EDX analysis (Figure 4, Table 3). The SEM-EDX images in Figure 4 demonstrate that the raw CFA mullite was represented by the spheres with a smooth surface. After desilication, the porosity of the particles was greatly increased, which was confirmed by the BET analysis in our previous study [32]. 
The specific surface area of the raw CFA is $0.81 \mathrm{~m}^{2} \mathrm{~g}^{-1}$, whereas the specific surface area of the DCFA- $15.70 \mathrm{~m}^{2} \mathrm{~g}^{-1}$. Figure $4 \mathrm{~d}$ shows that mullite acicular particles remain after the amorphous glassy phase dissolution from the surface. The agglomerate of the acicular mullite particles is spherical, as it was in the raw CFA. Magnetite is also represented by spheres (Figure 4c). The EDX analysis of magnetite and mullite particles is shown in Table 3. The high porosity of the DCFA and exposure of the acicular mullite particles explains the increase in its reactivity. Therefore, the subsequent alkali or acid mullite leaching can be accomplished under atmospheric pressure.

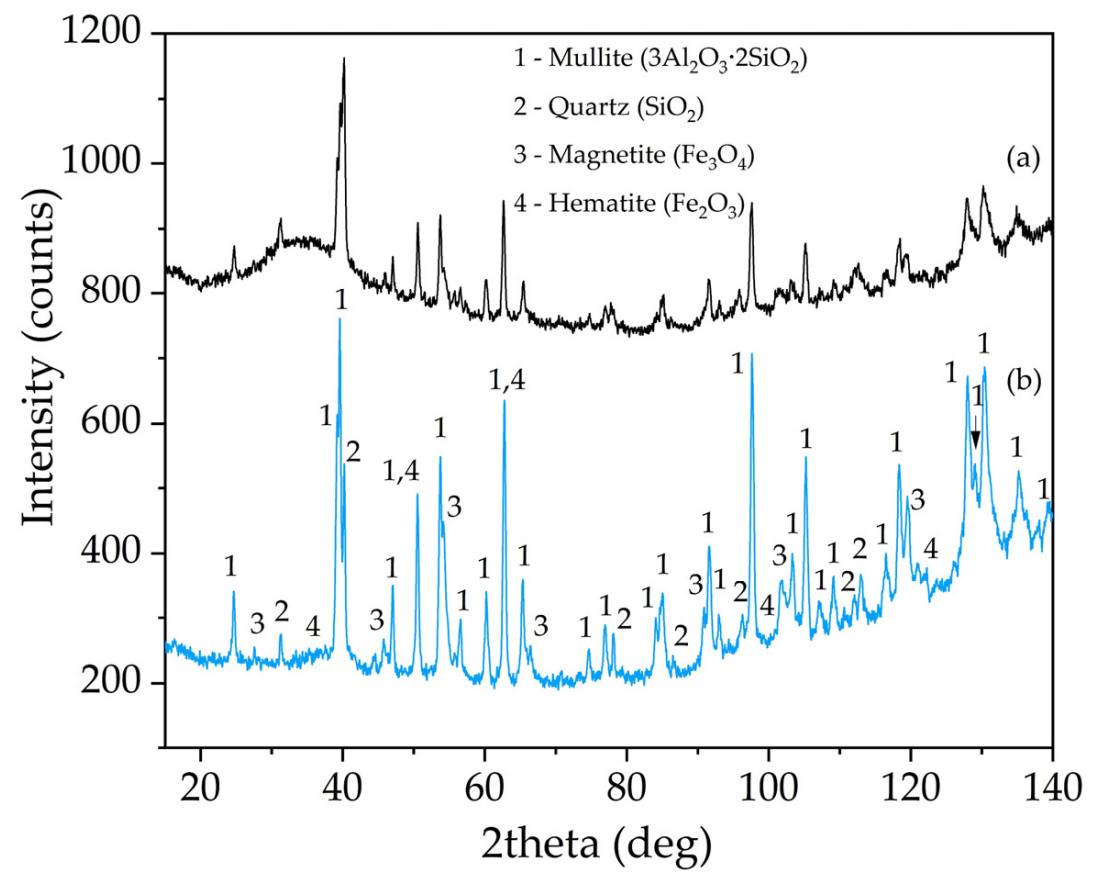

Figure 3. XRD pattern of the CFA from Reftinskaya TPP, Asbest, Russia (a) and DCFA (b).

Table 2. Semi-quantitative analysis of mineral phases in DCFA.

\begin{tabular}{cc}
\hline Phase & Content $\%$ \\
\hline Mullite & 78.4 \\
Quartz & 10.7 \\
Magnetite & 7.3 \\
Hematite & 3.6 \\
Total & 100 \\
\hline
\end{tabular}

\subsection{The Effect of Leaching Parameters on the Mullite Dissolution}

In this research, the mullite atmospheric leaching from DCFA by highly concentrated alkaline solutions was investigated using SANN and SCM. The chemical reaction of the interaction of mullite with caustic alkali can be represented by Equation (2).

$$
3 \mathrm{Al}_{2} \mathrm{O}_{3} \cdot 2 \mathrm{SiO}_{2(\mathrm{~s})}+10 \mathrm{NaOH}(\mathrm{aq})+7 \mathrm{H}_{2} \mathrm{O}_{(\mathrm{l})}=6 \mathrm{NaAl}(\mathrm{OH})_{4(\mathrm{aq})}+2 \mathrm{Na}_{2} \mathrm{SiO}_{3}(\mathrm{aq}) \cdot
$$

As was revealed in our previous study [32], the use of high alkaline concentrations and L:S ratios exclude the DSP formation via retention of Si in the metastable area. This allows the complete extraction of alumina from fly ash despite how much silica was in the raw CFA. Moreover, the boiling point of highly concentrated $\mathrm{NaOH}$ solution is higher than $120^{\circ} \mathrm{C}$ [47]. This allows us to use temperatures above $100{ }^{\circ} \mathrm{C}$ without high-pressure equipment. The matrix of experiments and the results of $\mathrm{Al}$ and $\mathrm{Si}$ extraction degree are shown in Table 4. 


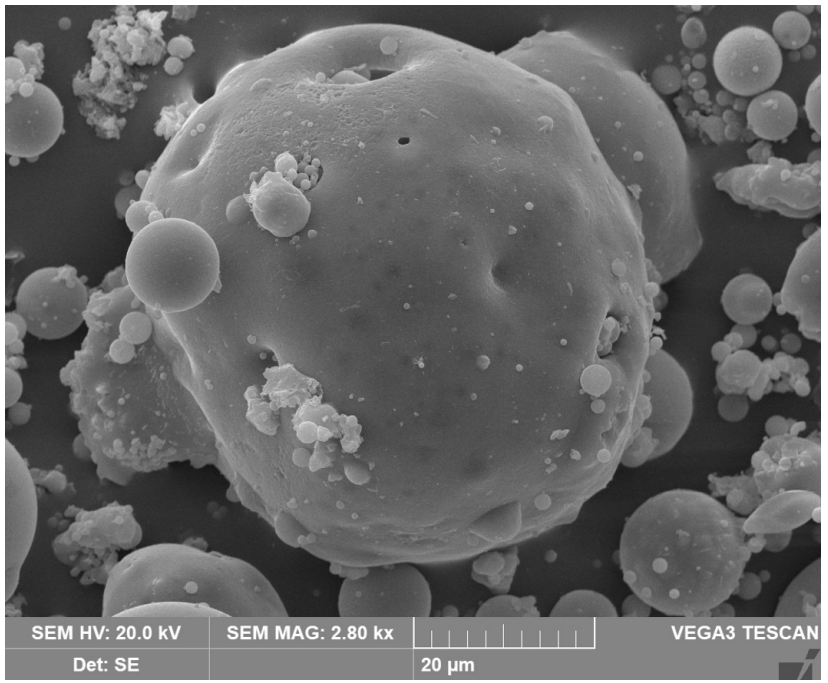

(a)

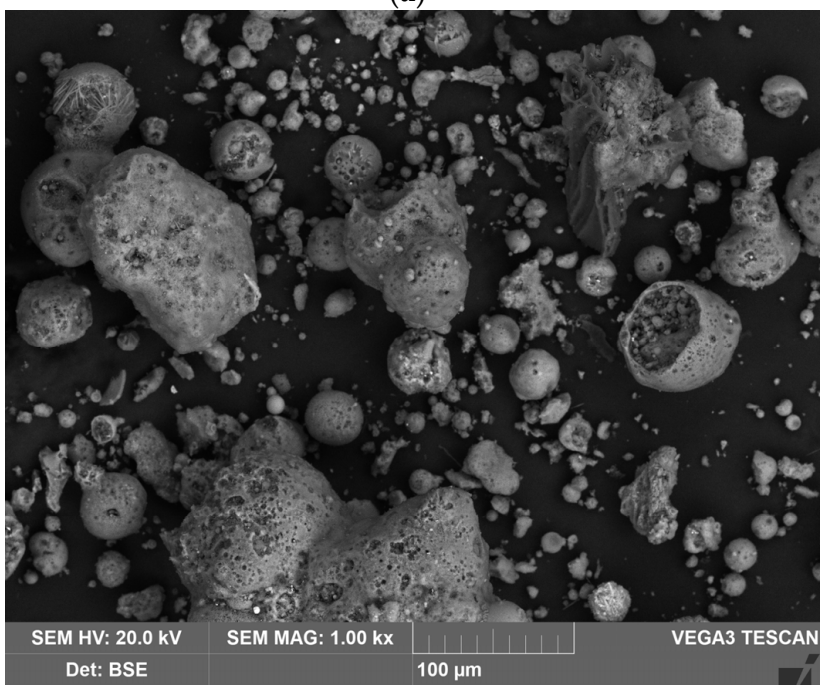

(c)

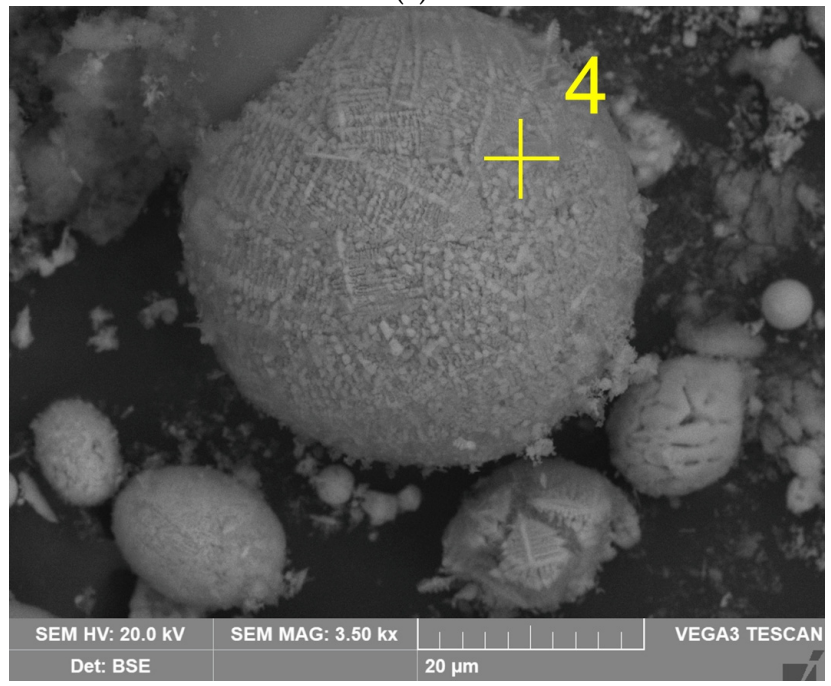

(e)

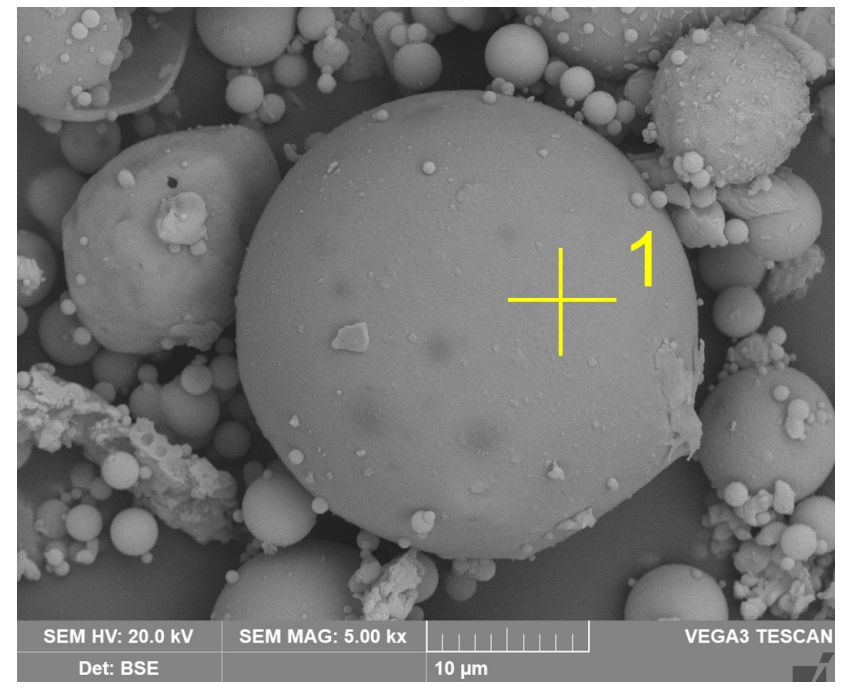

(b)

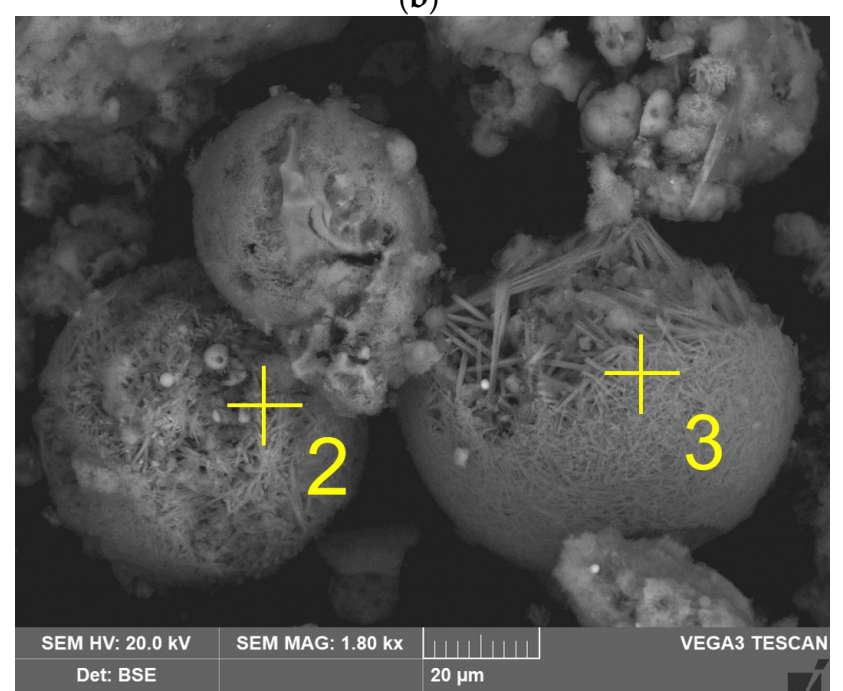

(d)

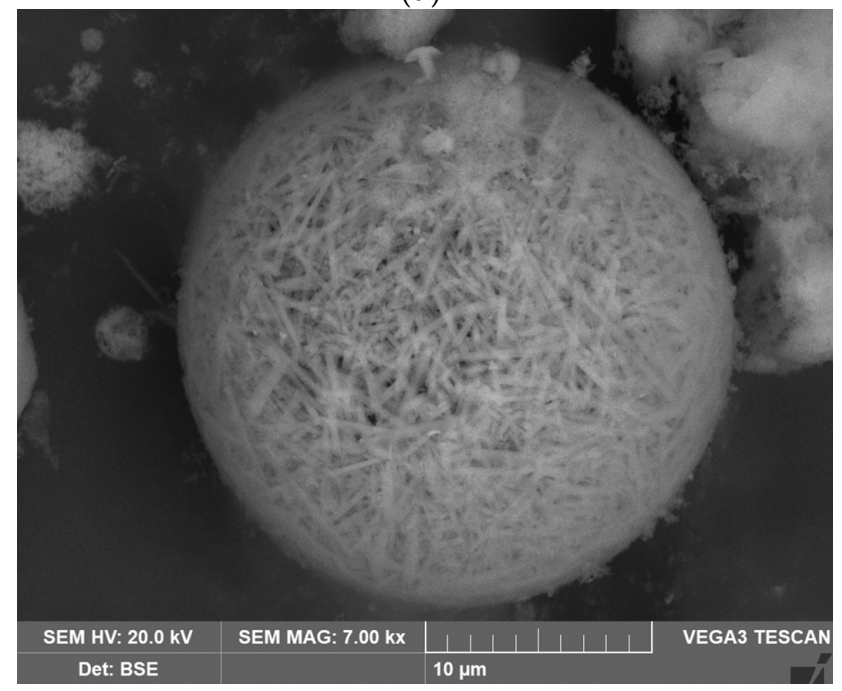

(f)

Figure 4. The SEM images of CFA at magnitude 2800 (a); mullite covered by the amorphous glassy phase at magnitude 5000 (b); DCFA at magnitude 1000 (c); DCFA at magnitude 1800 (d); magnetite particles at magnitude 3500 (e); spherical agglomerate of mullite particles at magnitude 7000 (f). 
Table 3. The result of EDX analysis of the raw CFA and DCFA (see Figure 4 for the spectra numbers).

\begin{tabular}{ccccccccc}
\hline Spectrum & $\mathbf{O}$ & $\mathbf{S i}$ & $\mathbf{A 1}$ & $\mathbf{C a}$ & $\mathbf{F e}$ & $\mathbf{T i}$ & $\mathbf{M g}$ & Phase \\
\hline 1 & 48.9 & 28.7 & 19.8 & 0.3 & 1.2 & - & 0.5 & Mullite covered by A-S ${ }^{1}$ \\
2 & 37.3 & 23.3 & 37.7 & - & - & 1.0 & - & Mullite \\
3 & 42.3 & 17.1 & 40.6 & - & - & - & - & Mullite \\
4 & 28.4 & 2.2 & 6.6 & 1.7 & 56.7 & 2.0 & Magnetite \\
\hline \multicolumn{7}{c}{ 1_amorphous glassy mass. }
\end{tabular}

Table 4. The matrix for planning experiments and the results of $\mathrm{Al}$ and $\mathrm{Si}$ extraction degree.

\begin{tabular}{|c|c|c|c|c|c|c|c|}
\hline Time (min) & $\begin{array}{c}\text { Temperature } \\
\left({ }^{\circ} \mathrm{C}\right)\end{array}$ & $\begin{array}{l}\text { L:S Ratio } \\
\text { (mL/g) }\end{array}$ & $\begin{array}{c}r_{0} \\
(\mu \mathrm{m})\end{array}$ & $\begin{array}{c}\mathrm{C}_{\mathrm{Na}_{2} \mathrm{O}} \\
\left(\mathrm{g} \mathrm{L}^{-1}\right)\end{array}$ & $\begin{array}{l}\mathrm{C}_{\mathrm{Al}_{2} \mathrm{O}_{3}}{ }^{2} \\
\left(\mathrm{~g} \mathrm{~L}^{-1}\right)\end{array}$ & $\begin{array}{c}\text { Al Extraction } \\
(\%)\end{array}$ & $\begin{array}{c}\text { Si Extraction } \\
(\%)\end{array}$ \\
\hline 10 & 120 & 20 & 48 & 400 & 0 & 48.00 & 60.40 \\
\hline 30 & 120 & 20 & 48 & 400 & 0 & 66.82 & 78.11 \\
\hline 40 & 120 & 20 & 48 & 400 & 0 & 76.07 & 83.77 \\
\hline 60 & 120 & 20 & 48 & 400 & 0 & 84.04 & 88.22 \\
\hline 30 & 120 & 10 & 48 & 400 & 0 & 48.30 & 60.00 \\
\hline 22.5 & 120 & 15 & 48 & 400 & 0 & 54.20 & 66.00 \\
\hline 40 & 110 & 20 & 48 & 400 & 0 & 55.80 & 66.59 \\
\hline 60 & 110 & 20 & 48 & 400 & 0 & 67.00 & 76.00 \\
\hline 15 & 100 & 20 & 48 & 400 & 0 & 26.70 & 33.85 \\
\hline 60 & 100 & 20 & 48 & 400 & 0 & 45.79 & 60.40 \\
\hline 45 & 120 & 20 & 48 & 330 & 0 & 59.40 & 66.59 \\
\hline 10 & 120 & 20 & 48 & 330 & 0 & 38.90 & 51.20 \\
\hline 20 & 120 & 20 & 48 & 330 & 0 & 46.70 & 59.43 \\
\hline 60 & 120 & 20 & 48 & 330 & 0 & 66.10 & 76.51 \\
\hline 10 & 120 & 20 & 48 & 360 & 0 & 39.90 & 53.40 \\
\hline 30 & 120 & 20 & 48 & 360 & 0 & 59.81 & 74.10 \\
\hline 60 & 120 & 20 & 48 & 360 & 0 & 74.04 & 82.51 \\
\hline 10 & 120 & 15 & 48 & 400 & 0 & 39.90 & 53.10 \\
\hline 60 & 120 & 15 & 48 & 400 & 0 & 74.04 & 81.05 \\
\hline 10 & 120 & 10 & 48 & 400 & 0 & 28.50 & 35.10 \\
\hline 60 & 120 & 10 & 48 & 400 & 0 & 58.10 & 73.20 \\
\hline 10 & 110 & 20 & 48 & 400 & 0 & 28.63 & 35.20 \\
\hline 10 & 100 & 20 & 48 & 400 & 0 & 20.40 & 30.40 \\
\hline 30 & 100 & 20 & 48 & 400 & 0 & 37.60 & 52.30 \\
\hline 60 & 100 & 20 & 48 & 400 & 0 & 45.70 & 58.67 \\
\hline 10 & 120 & 20 & 87 & 400 & 0 & 37.30 & 49.12 \\
\hline 30 & 120 & 20 & 87 & 400 & 0 & 58.20 & 73.60 \\
\hline 60 & 120 & 20 & 87 & 400 & 0 & 67.80 & 81.30 \\
\hline 30 & 120 & 20 & 65 & 400 & 0 & 63.40 & 77.50 \\
\hline 30 & 120 & 20 & 65 & 400 & 190 & 28.13 & 46.87 \\
\hline 30 & 120 & 20 & 65 & 400 & 380 & 19.62 & 37.18 \\
\hline 10 & 120 & 20 & 65 & 400 & 190 & 16.50 & 35.05 \\
\hline 40 & 120 & 20 & 65 & 400 & 190 & 33.40 & 49.80 \\
\hline 60 & 120 & 20 & 65 & 400 & 190 & 44.52 & 50.20 \\
\hline 10 & 120 & 20 & 65 & 400 & 380 & 9.91 & 29.70 \\
\hline 40 & 120 & 20 & 65 & 400 & 380 & 22.24 & 39.51 \\
\hline 60 & 120 & 20 & 65 & 400 & 380 & 26.40 & 44.87 \\
\hline
\end{tabular}

As was shown by Xie et al. and Shokri [42,43], using machine learning allows us to get more accurate models than using mathematical methods. The best fit SANN model obtained for the extraction of alumina is a multilayer perceptron (MLP) 6.9.1, where six is the number of input parameters, nine is the number of hidden layers, and one is the number of output layers. Experimental data and values predicted using the resulting network are in good agreement $\left(\mathrm{R}^{2}=0.988\right)$, Figure 5 .

The response surfaces predicted by the SANN for Al extraction degree depending on the leaching duration $(\tau, \mathrm{min})$, the L:S ratio $(\mathrm{L}: \mathrm{S})$, the temperature $\left(\mathrm{T},{ }^{\circ} \mathrm{C}\right), \mathrm{Na}_{2} \mathrm{O}$ concen- 
tration $\left(\mathrm{C}_{\mathrm{Na} 2 \mathrm{O}}, \mathrm{g} \mathrm{L}^{-1}\right)$, initial $\mathrm{Al}_{2} \mathrm{O}_{3}$ concentration $\left(\mathrm{C}_{\mathrm{Al} 2 \mathrm{O} 3}{ }^{0}, \mathrm{~g} \mathrm{~L}^{-1}\right)$, and the initial mean particle size $\left(\mathrm{r}^{0}, \mu \mathrm{m}\right)$ are shown on Figure 6.

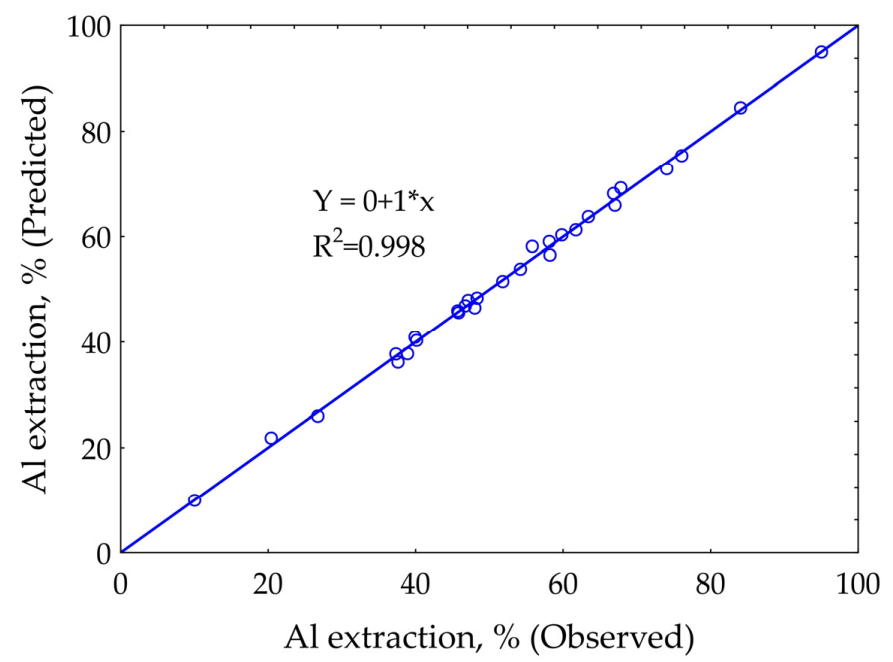

Figure 5. Coefficient of determination for SANN-based alumina extraction from DCFA model.

$\mathrm{L}: \mathrm{S}=20, \mathrm{r}_{\mathrm{o}}=48 \mu \mathrm{m}, \mathrm{C}_{\mathrm{Na} 2 \mathrm{O}}=400 \mathrm{~g} \mathrm{~L}^{-1}, \mathrm{C}_{\mathrm{Al} 2 \mathrm{O} 3}{ }^{0}=0 \mathrm{~g} \mathrm{~L}^{-1}$

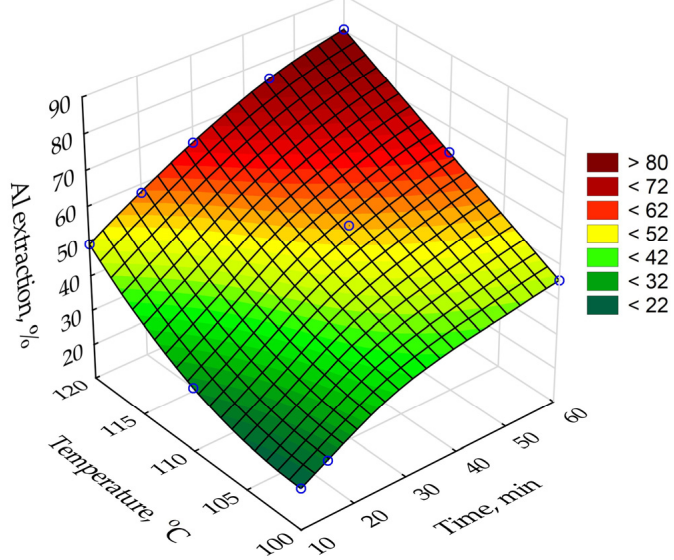

(a)

$\mathrm{T}=120^{\circ} \mathrm{C}, \mathrm{L}: \mathrm{S}=20, \mathrm{C}_{\mathrm{Na} 2 \mathrm{O}}=400 \mathrm{~g} \mathrm{~L}^{-1}, \mathrm{C}_{\mathrm{Al} 2 \mathrm{O}}{ }^{0}=0 \mathrm{~g} \mathrm{~L}^{-1}$

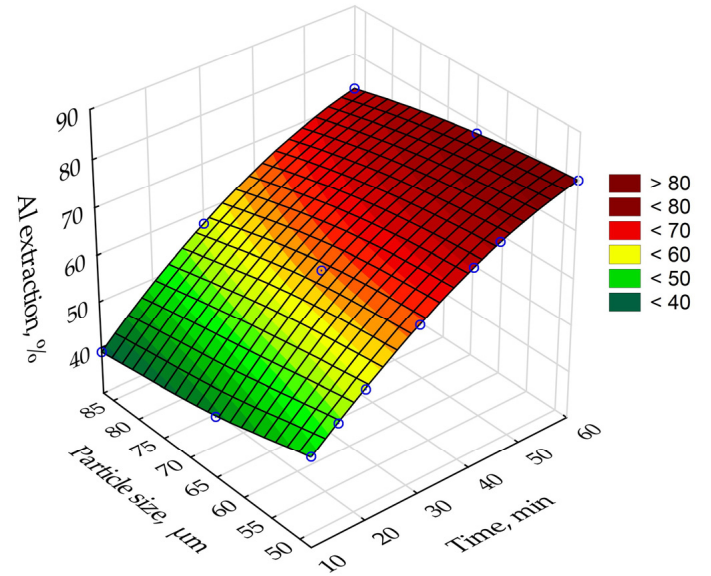

(c)

$$
\mathrm{T}=120{ }^{\circ} \mathrm{C}, \mathrm{r}_{\mathrm{O}}=48 \mu \mathrm{m}, \mathrm{C}_{\mathrm{Na} 2 \mathrm{O}}=400 \mathrm{~g} \mathrm{~L}^{-1}, \mathrm{C}_{\mathrm{Al} 2 \mathrm{O} 3}^{0}=0 \mathrm{~g} \mathrm{~L}^{-1}
$$

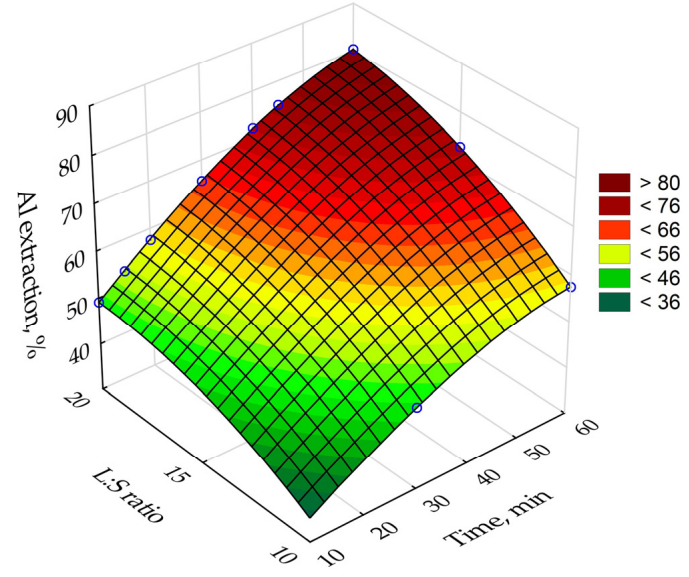

(b)

$\mathrm{T}=120{ }^{\circ} \mathrm{C}, \mathrm{L}: \mathrm{S}$ ratio $=20, \mathrm{r}_{\mathrm{o}}=48 \mu \mathrm{m}, \mathrm{C}_{\mathrm{Al} 2 \mathrm{O} 3}{ }^{0}=0 \mathrm{~g} \mathrm{~L}^{-1}$

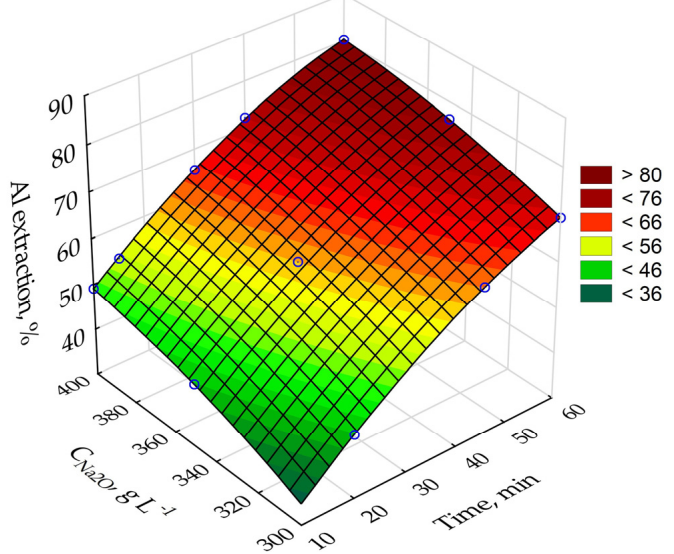

(d)

Figure 6. Cont. 


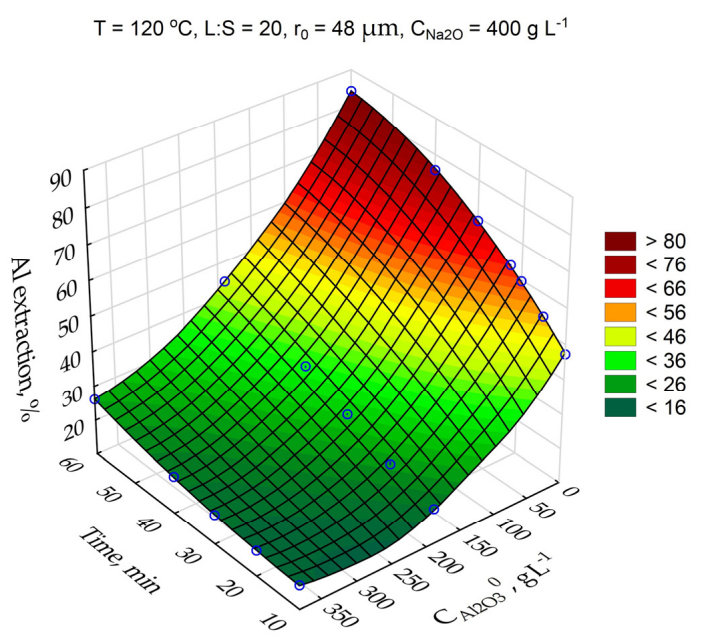

(e)

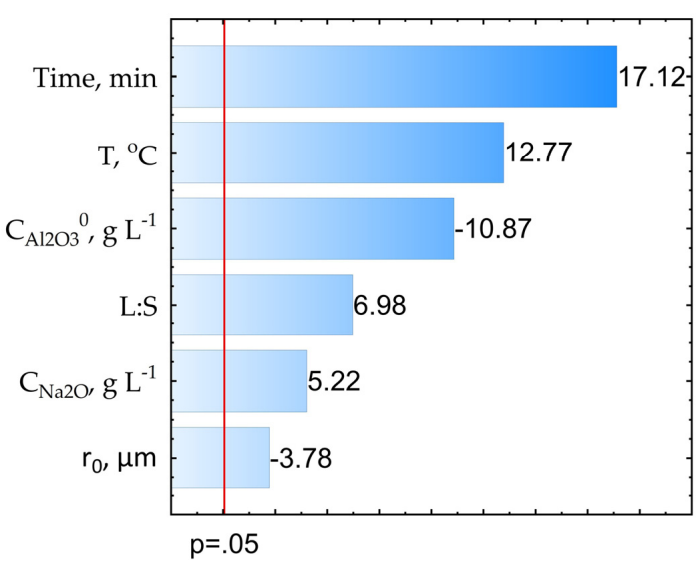

Standardized effect

(f)

Figure 6. Neural network response surfaces for effect of time and temperature on the Al extraction (a); effect of time and L:S ratio on the $\mathrm{Al}$ extraction (b); effect of time and particle size on the $\mathrm{Al}$ extraction (c); effect of time and $\mathrm{Na}_{2} \mathrm{O}$ concentration on the $\mathrm{Al}$ extraction (d); effect of time and initial $\mathrm{Al}_{2} \mathrm{O}_{3}$ concentration on the $\mathrm{Al}$ extraction (e); Pareto chart (f). Blue points are the experimental data.

The major effect (Figure 6) on Al extraction degree is caused by leaching time, temperature, the $\mathrm{Al}$ concentration in the solution, and the L:S ratio. Increasing the temperature from 100 to $120{ }^{\circ} \mathrm{C}$ allows us to increase the $\mathrm{Al}$ extraction degree after $60 \mathrm{~min}$ from 46 to $84 \%$. This may indicate that the surface chemical reaction is the limiting stage of the process. An increase in the initial concentration of $\mathrm{Al}_{2} \mathrm{O}_{3}$ in the solution from 0 to $380 \mathrm{~g} \mathrm{~L}^{-1}$ leads to a decrease in $\mathrm{Al}$ extraction degree from 84 to $51 \%$. This is connected to the fact that the solution is already sufficiently saturated with aluminum, and approaching the equilibrium concentration can lead to a reverse precipitation reaction. In this situation, external diffusion could be the limiting stage. The effect of the average particle size and the $\mathrm{Na}_{2} \mathrm{O}$ concentration is significantly lower, which is more common for the kinetic limiting stage. This observation is also confirmed by the results presented in the Pareto chart (Figure 6f). The kinetic studies were conducted to understand which stage is limiting the leaching process.

\subsection{Kinetic Study}

The SANN model obtained on the basis of the experimental data from Table 4 was used to study kinetics of the leaching process with help of various shrinking core models [48]. These models imply that during the leaching of particles, their core shrinks to the center, leaving behind a layer of inert product. In this case, substances insoluble in alkali can serve as an inert product as well as refractory compounds that require increased pressure to leach.

Three models of the shrinking core were used in this work. Equation (3) can be used to describe a process limited by a surface chemical reaction:

$$
\left[1-(1-X)^{1 / 3}\right]=k_{1} \mathrm{t},
$$

where $\mathrm{X}$ is the degree of conversion; $\mathrm{k}_{\mathrm{i}}$ is the apparent rate constant of Equation (3); $\mathrm{t}$ is the leaching time, min.

When the leaching rate is limited by the diffusion through inert product layer, the kinetic Equation (4) can be used:

$$
\left[1-2 / 3 \mathrm{X}-(1-\mathrm{X})^{2 / 3}\right]=\mathrm{k}_{2} \mathrm{t} .
$$

where $k_{2}$ is the apparent rate constant of Equation (4).

If the leaching rate is limited by the diffusion through the liquid film, then Equation (5) can be used:

$$
X=k_{3} t .
$$


where $\mathrm{k}_{3}$ is the apparent rate constant of Equation (5).

The non-linear least squares method was used to fit the obtained data into the equations of the shrinking core model.

Equations (3) and (4) are best suited to describing the leaching process of mullite (Figure 7). The data presented on Figure $7 \mathrm{a}, \mathrm{b}$ show that at temperatures below $110^{\circ} \mathrm{C}$ and leaching time less than $20 \mathrm{~min}$, the surface chemical reaction shrinking core model provides the best fit to the experimental data. While at temperatures above $110{ }^{\circ} \mathrm{C}$ and leaching time of more than $20 \mathrm{~min}$ (Figure 8a), the data are more suitable for the modeling of diffusion through the product layer. Therefore, Equation (3) was chosen to fit data obtained by varying other parameters (Figure 8). The fixed parameters, if not stated otherwise, were as follows: $\mathrm{T}=120^{\circ} \mathrm{C}, \mathrm{L}: \mathrm{S}=20, \mathrm{C}_{\mathrm{Na} 2 \mathrm{O}}=400 \mathrm{~g} \mathrm{~L}^{-1}, \mathrm{r}_{0}=48 \mu \mathrm{m}, \mathrm{C}_{\mathrm{Al} 2 \mathrm{O} 3}{ }^{0}=0 \mathrm{~g} \mathrm{~L}^{-1}$.

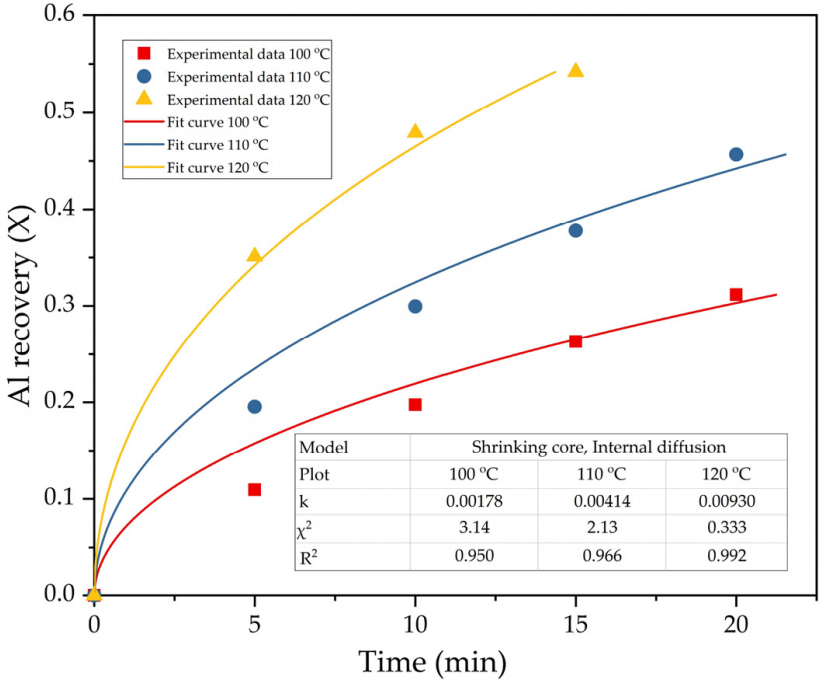

(a)

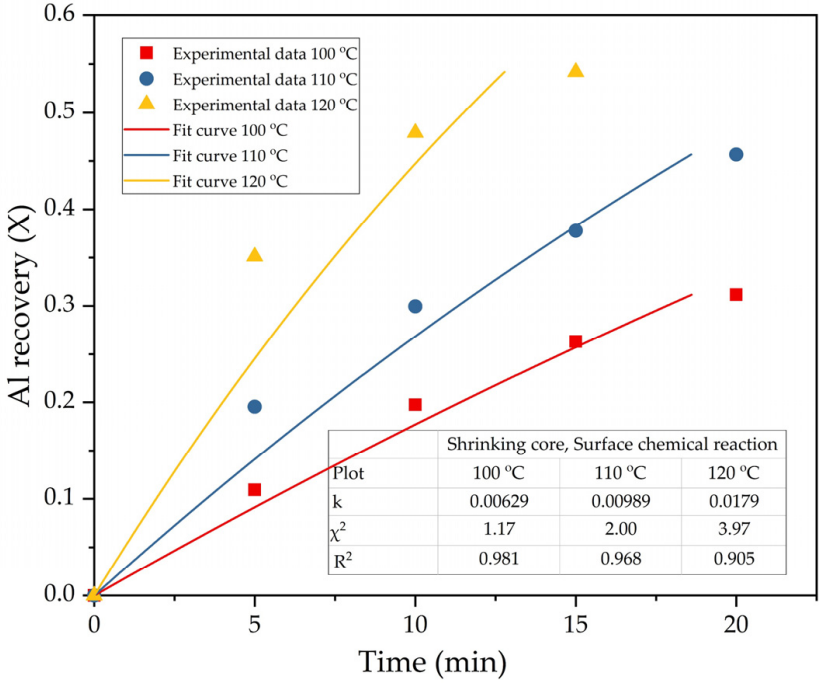

(b)

Figure 7. The results of fitting obtained data (points) to Equation (2) and Equation (3) (lines): the diffusion through the product layer (a); the surface chemical reaction $(\mathbf{b})$ for the effect of temperature.

Leaching efficiency at $\mathrm{T}=100{ }^{\circ} \mathrm{C}$ is much lower than at $\mathrm{T}=120^{\circ} \mathrm{C}$; this explains why the shrinking core model for surface chemical reaction is more suitable at low temperature (Figure $7 \mathrm{~b}$ ). At high temperatures and leaching time, a layer of inert product becomes thicker. Therefore, the leaching rate can be limited by the diffusion of the alkaline solution through the product layer. The nature of the product layer appearing during mullite leaching in case of $\mathrm{Al}_{2} \mathrm{O}_{3}$ and $\mathrm{SiO}_{2}$ simultaneous extraction requires further research using SEM-EDX analysis.

An increase in the average particle size only slightly reduces the leaching efficiency (Figure $8 b$ ). The low effect of particle size can relate to the high porosity of DCAF. However, according to Gok et al. [49], if diffusion through the product layer controls the reaction rate, there should be a linear relation between the apparent rate constant $\left(\mathrm{k}_{2}\right)$ and the reverse square of particle radius $\left(1 / \mathrm{r}_{0}{ }^{2}\right)$. A dependence between $\mathrm{k}_{2}$ obtained in Figure $8 \mathrm{~b}$ and $1 / \mathrm{r}_{0}{ }^{2}$ values is shown in Figure $8 \mathrm{f}$. Linear relation with $\mathrm{R}^{2}=0.97$ confirms that diffusion through the product layer is the rate-limiting step for this process.

The high effect of solution concentration and L:S ratio (Figure 8c-e) indicates that the amount of free alkaline in the solution is essential for the leaching process, since DSP begins to form at a low L:S ratio and high initial alumina concentration [41].

The apparent activation energy $\left(E_{a}\right)$ was calculated using the values of $k_{2}$ obtained in Figure 8a (constant rates at different temperatures). The linear fit shown in Figure 9 was used to determine the $\mathrm{E}_{\mathrm{a}}$ according to the Arrhenius Equation (6):

$$
\mathrm{k}=\mathrm{k}_{0} \exp \left(-\mathrm{E}_{\mathrm{a}} / \mathrm{RT}\right) \text {. }
$$

where $\mathrm{k}_{0}$ is the pre-exponential factor; $\mathrm{E}_{\mathrm{a}}$ is the apparent activation energy, $\mathrm{kJ} / \mathrm{mol} ; \mathrm{R}$ is the universal gas constant, $8.314 \mathrm{~J} / \mathrm{mol} \cdot \mathrm{K}$; and $\mathrm{T}$ is the reaction temperature, $\mathrm{K}$. 


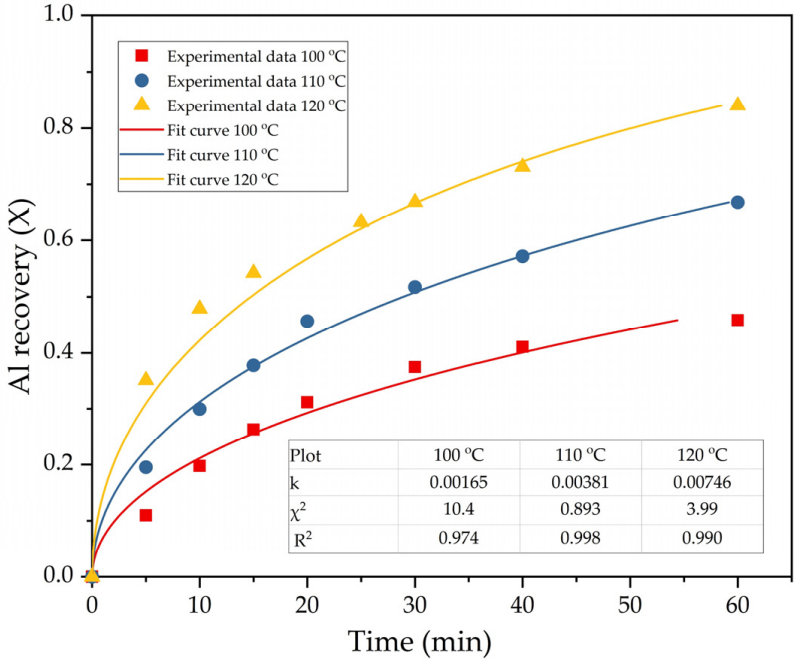

(a)

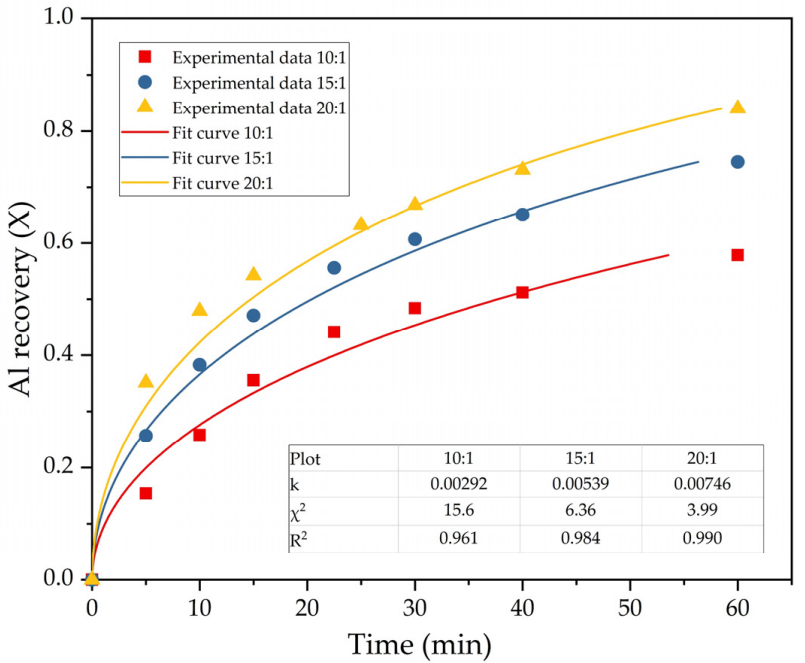

(c)

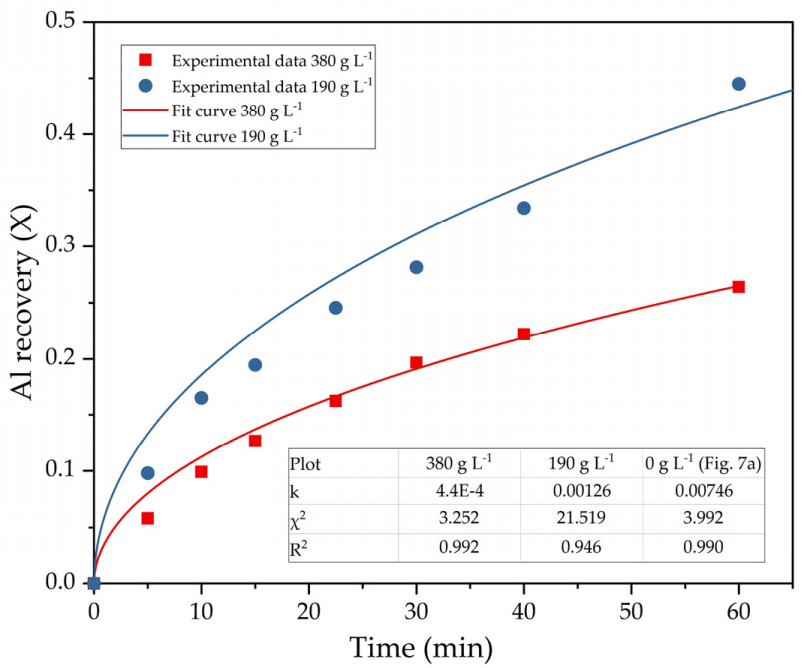

(e)

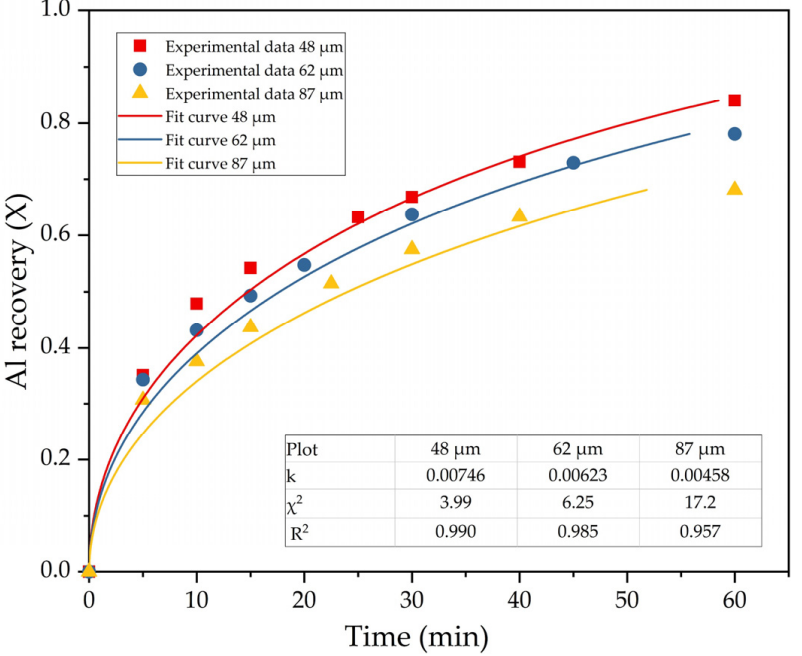

(b)

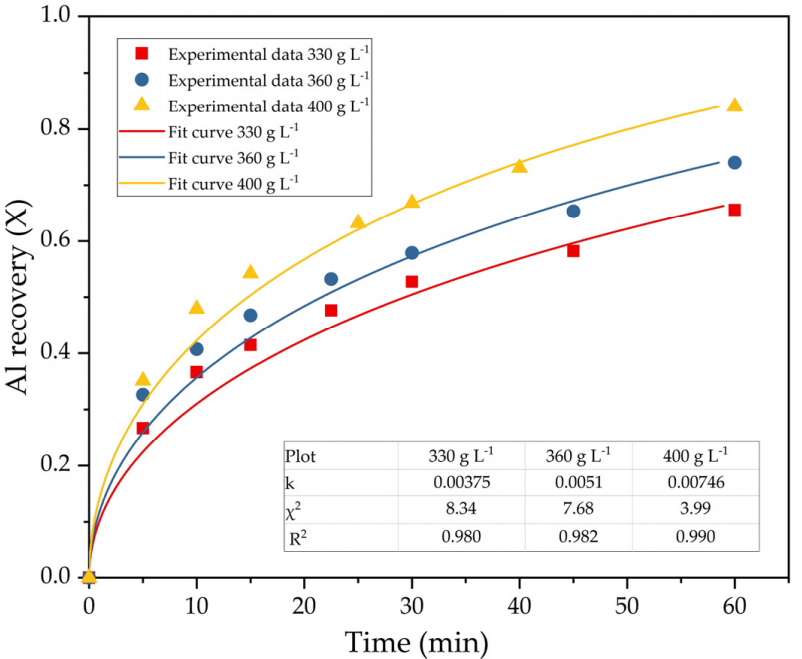

(d)

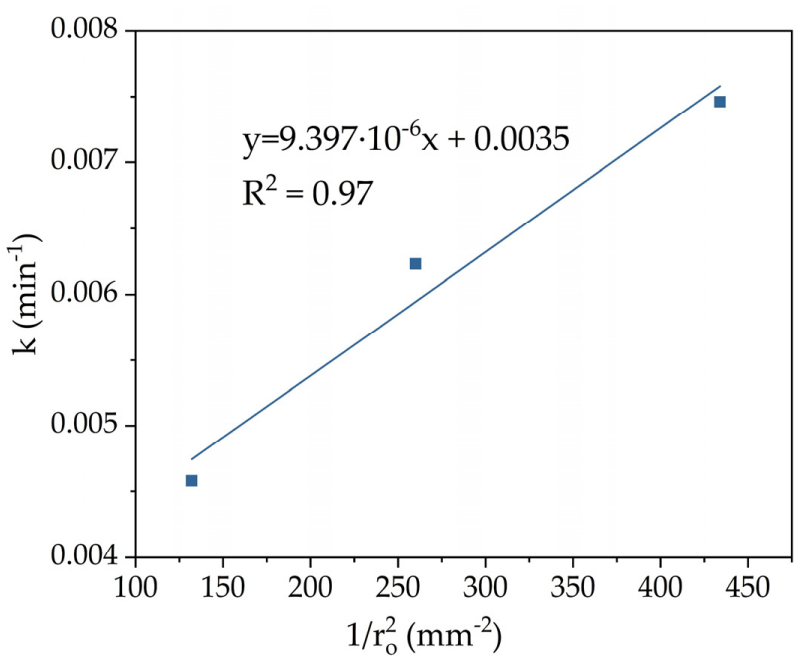

(f)

Figure 8. The results of fitting obtained data (points) to Equation (3) (lines): the diffusion through the product layer for the effect of temperature (a); the diffusion through the product layer for the effect of particle size (b); the diffusion through the product layer for the effect of L:S ratio (c); the diffusion through the product layer for the effect of $\mathrm{C}_{\mathrm{Na} 2 \mathrm{O}}$ (d); the diffusion through the product layer for the effect of $\mathrm{C}_{\mathrm{Al} 2 \mathrm{O} 3}{ }^{0}$ (e) and relation between the apparent rate constant and the reverse square of particle radius (f). 


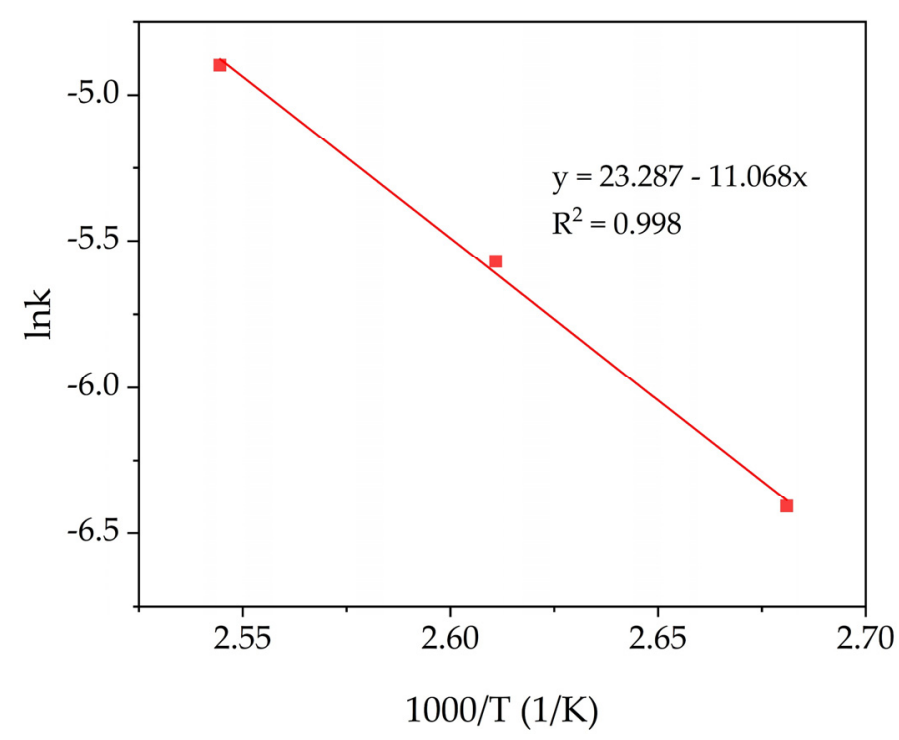

Figure 9. Relationship between lnk from Figure 7a and 1000/T.

According to the slope obtained in Figure 9, the $E_{a}$ value is $92.0 \mathrm{~kJ} / \mathrm{mol}$. Therefore, it implies that the rate-limiting step of leaching of mullite, especially at low temperatures, is the chemical reaction. This is because the leaching of refractory mullite requires high activation energy even after the dissolution of glassy amorphous mass from the surface of the particles. Thus, according to $\mathrm{SCM}$ and the $\mathrm{E}_{\mathrm{a}}$ value, the process of mullite dissolution is limited by the surface chemical reaction at low temperatures and leaching time and by diffusion through the product layer at the $120^{\circ} \mathrm{C}$ and later stages of leaching. To reveal the nature of a product layer that inhibits the leaching process, solid residue characterization was performed.

\subsection{Solid Residue Characterization}

The chemical composition of the solid residue obtained at $\mathrm{T}=120^{\circ} \mathrm{C}$, L:S ratio $=$ 20, $\tau=60 \mathrm{~min}, \mathrm{C}_{\mathrm{Na} 2 \mathrm{O}}=400 \mathrm{~g} \mathrm{~L}^{-1}$, and $\mathrm{C}_{\mathrm{Al} 2 \mathrm{O} 3}{ }^{0}=0 \mathrm{~g} \mathrm{~L}^{-1}$ is presented in Table 5. The yield of solid residue was $33.95 \%$ of the initial DCFA sample mass. It could be seen that iron and carbon content have increased significantly in the residue contrary to the initial DCFA. A high amount of silica and alumina still can be observed, which points out that not all mullite was extracted after $60 \mathrm{~min}$ of leaching. However, the extraction degree of $\mathrm{Si}$ (Table 4) and $\mathrm{Al}$ (on DCFA mass basis) at these parameters were 88.2 and $84.0 \mathrm{wt}$. \%, respectively. On the raw CFA mass basis, $\mathrm{Si}$ and $\mathrm{Al}$ extraction degree at the mullite leaching stage were 17.0 and $66.7 \mathrm{wt}$. \%, respectively. Thus, the $\mathrm{Si}$ and $\mathrm{Al}$ extraction degree from the raw CFA after two leaching stages were $80.7+17.0=97.7 \%$ and $17.3+66.7=84.0 \%$, respectively. At the same time, $\mathrm{Na}_{2} \mathrm{O}$ content was still very low; it means that DSP was not formed during the leaching of DCFA at such an $\mathrm{L}: \mathrm{S}$ ratio and $\mathrm{Na}_{2} \mathrm{O}$ concentration.

Table 5. Chemical composition of the solid residue after DCFA leaching by $\mathrm{NaOH}$ at $\mathrm{T}=120^{\circ} \mathrm{C}, \mathrm{L}: \mathrm{S}$ ratio $=20, \tau=60 \mathrm{~min}, \mathrm{C}_{\mathrm{Na} 2 \mathrm{O}}=400 \mathrm{~g} \mathrm{~L}^{-1}, \mathrm{C}_{\mathrm{Al} 2 \mathrm{O} 3}{ }^{0}=0 \mathrm{~g} \mathrm{~L}^{-1}$.

\begin{tabular}{cccccccccc}
\hline \multicolumn{10}{c}{ Main Components, wt. \% } \\
\hline $\mathrm{SiO}_{2}$ & $\mathrm{Al}_{2} \mathrm{O}_{3}$ & $\mathrm{CaO}$ & $\mathrm{Fe}_{2} \mathrm{O}_{3}$ & $\mathrm{TiO}_{2}$ & $\mathrm{MgO}$ & $\mathrm{Na}_{2} \mathrm{O}$ & $\mathrm{K}_{2} \mathrm{O}$ & $\mathrm{LOI}$ & $\mathrm{C}$ \\
15.56 & 28.4 & 6.28 & 26.28 & 8.60 & 0.53 & 0.1 & 0.01 & 11.86 & 10.67 \\
\hline
\end{tabular}

The X-ray diffraction pattern of the solid residue after mullite leaching from DCFA is shown in Figure 10. The morphology and elemental composition of the solid residue particles were investigated by SEM-EDX (Figure 11 and Table 6). The surface area and porosity of the solid residue were studied by the BET method (Table 7). 


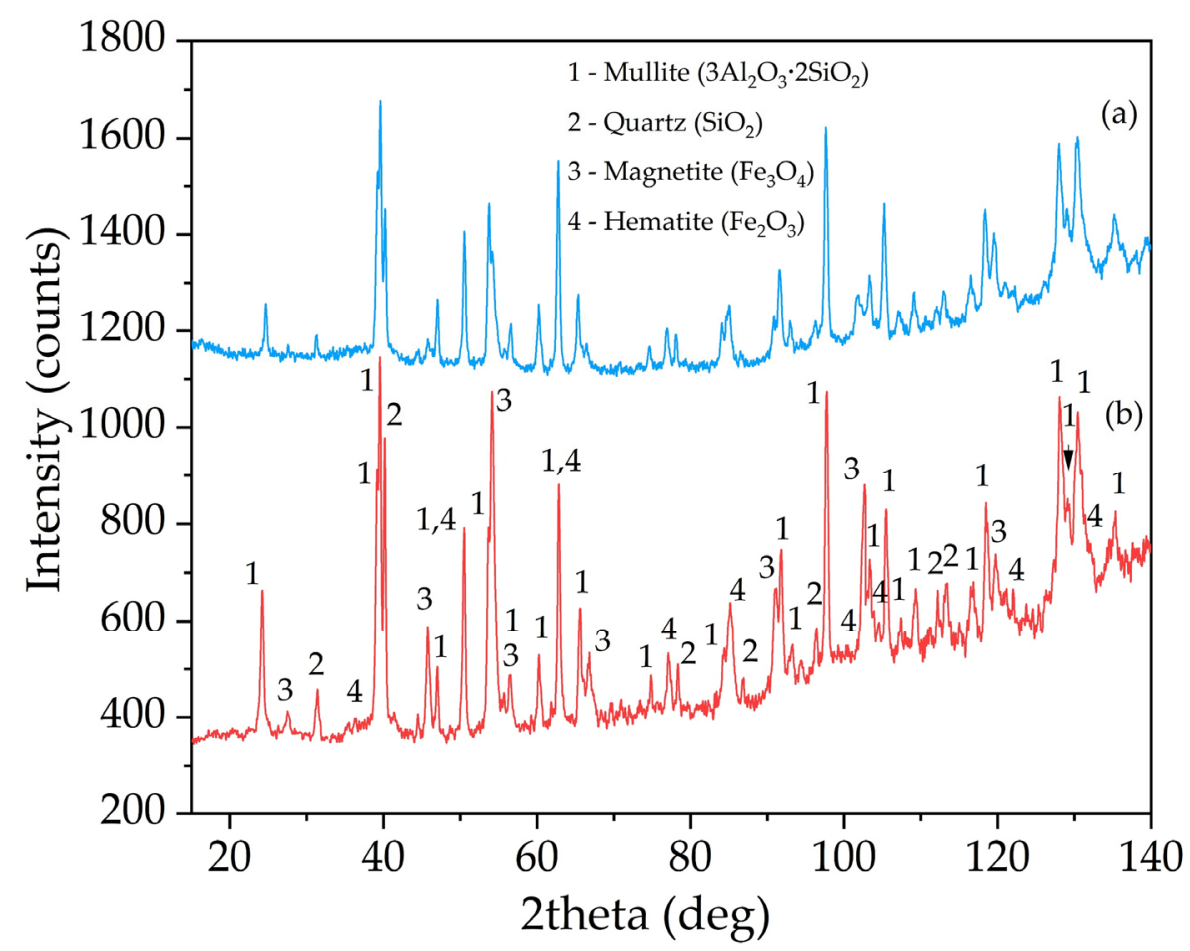

Figure 10. XRD pattern of the DCFA (a) the solid residue obtained after mullite leaching from DCFA at $\mathrm{T}=120^{\circ} \mathrm{C}$, L:S ratio $=20, \tau=60 \mathrm{~min}, \mathrm{C}_{\mathrm{Na} 2 \mathrm{O}}=400 \mathrm{~g} \mathrm{~L}^{-1}, \mathrm{C}_{\mathrm{Al} 2 \mathrm{O} 3}{ }^{0}=0 \mathrm{~g} \mathrm{~L}^{-1}$ (b).

Table 6. The result of EDX analysis of solid residue (see Figure 11 for the spectra numbers).

\begin{tabular}{|c|c|c|c|c|c|c|c|c|c|}
\hline Spectrum & $\mathrm{O}$ & Si & Al & $\mathrm{Ca}$ & $\mathbf{F e}$ & $\mathrm{Ti}$ & $\mathrm{Mg}$ & $\mathrm{C}$ & Phase \\
\hline 1 & 28.4 & 2.2 & 6.6 & 1.7 & 56.7 & 2.0 & 1.1 & - & Magnetite + Mullite \\
\hline 2 & 18.3 & 0.4 & 1.9 & - & 77.0 & 0.4 & 0.9 & - & Magnetite \\
\hline 3 & 57.4 & 10.0 & 28.8 & 0.7 & 1.9 & 1.3 & - & - & Mullite \\
\hline 4 & 22.1 & - & 3.8 & - & 70.8 & - & 2.2 & - & Magnetite \\
\hline 5 & 20.9 & - & 2.8 & - & 72.9 & - & 2.0 & - & Magnetite \\
\hline 6 & 18.5 & 0.4 & 2.5 & 0.4 & 74.6 & - & 2.6 & - & Magnetite \\
\hline 7 & 21.7 & 2.0 & 6.0 & 0.8 & 2.8 & 1.3 & - & 65.1 & $\mathrm{C}$ \\
\hline 8 & 43.0 & 5.2 & 18.7 & 1.4 & 27.2 & 0.7 & 3.2 & - & Magnetite + Mullite \\
\hline 9 & 44.8 & 34.0 & 13.9 & 1.3 & 3.5 & 2.5 & - & - & Mullite + Quartz \\
\hline 10 & 45.7 & 11.5 & 42.3 & - & - & - & - & - & Mullite \\
\hline 11 & 35.6 & - & 5.5 & - & 54.4 & - & 3.9 & - & Magnetite \\
\hline
\end{tabular}

Table 7. The textural properties and particle size of the DCFA (size fraction $+50-71 \mu \mathrm{m}$ ) and the solid residue after $\mathrm{NaOH}$ leaching at $\mathrm{T}=120^{\circ} \mathrm{C}, \mathrm{L}: \mathrm{S}$ ratio $=20, \tau=60 \mathrm{~min}$.

\begin{tabular}{cccc}
\hline Product & $\begin{array}{c}\text { Specific Surface } \\
\text { Area (BET) }\left(\mathbf{m}^{\mathbf{2}} \mathbf{g}^{-\mathbf{1})}\right.\end{array}$ & $\begin{array}{c}\text { Total Pore Volume } \\
\left(\mathbf{c m}^{\mathbf{3}} \mathbf{g}^{-\mathbf{1})}\right.\end{array}$ & Pore Diameter (nm) \\
\hline DCFA & 15.70 & 25 & 37.6 \\
Solid residue & 16.28 & 33 & 33.6 \\
\hline
\end{tabular}

As can be seen in Figure 10, the mullite peaks have not changed, while the magnetite peaks have increased significantly. Peaks of quartz were also increased in comparison with mullite. This fact suggests that only mullite is predominantly leached out, while the other phases remain unleached. The presence of the mullite peaks indicates that $60 \mathrm{~min}$ of leaching at $120^{\circ} \mathrm{C}$ and a high concentration of $\mathrm{Na}_{2} \mathrm{O}$ is not sufficient to dissolve minerals as refractory as mullite. However, according to chemical analysis and the yield of the residue, more than $80 \%$ of mullite was leached out, as well as quartz.

The data obtained above are confirmed by the SEM-EDX (Figure 11 and Table 6). Figure $11 \mathrm{a}, \mathrm{b}$ show that the spherical agglomerates of mullite particles are destroyed during the leaching process and the single acicular particles are seen on the surface. The EDX anal- 
ysis has been done to clarify the chemical composition of the particles (Table 6). According to the analysis, there are still spherical particles of magnetite (Figure 11f), non-porous mullite aggregates (Figure 11e), and nonuniform particles of quartz (Figure 11c).

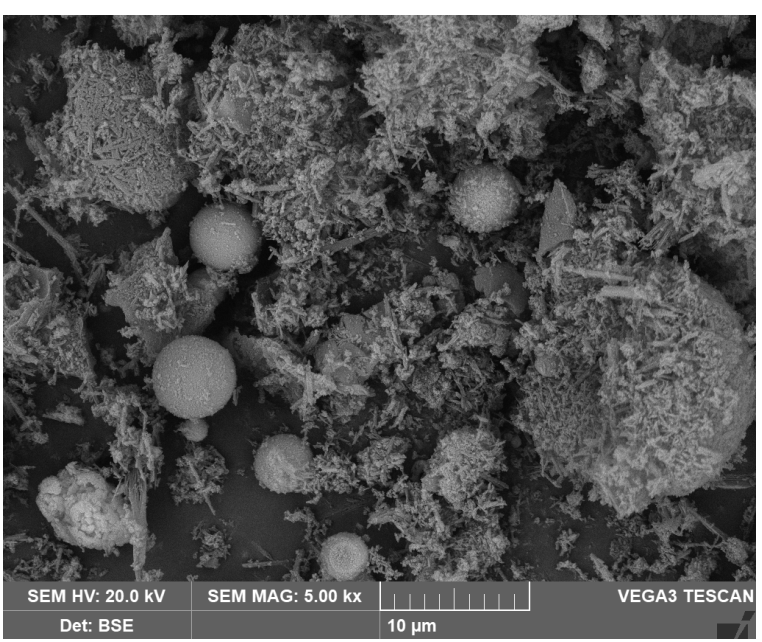

(a)

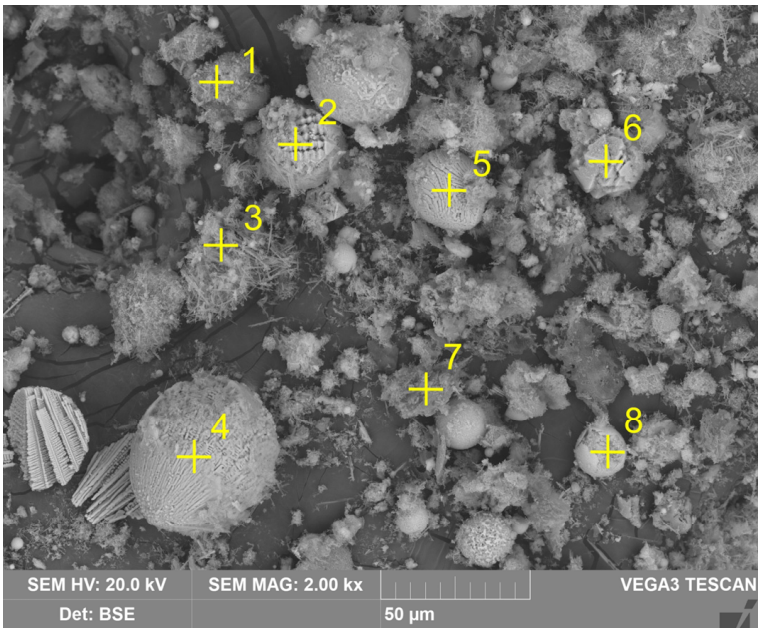

(c)

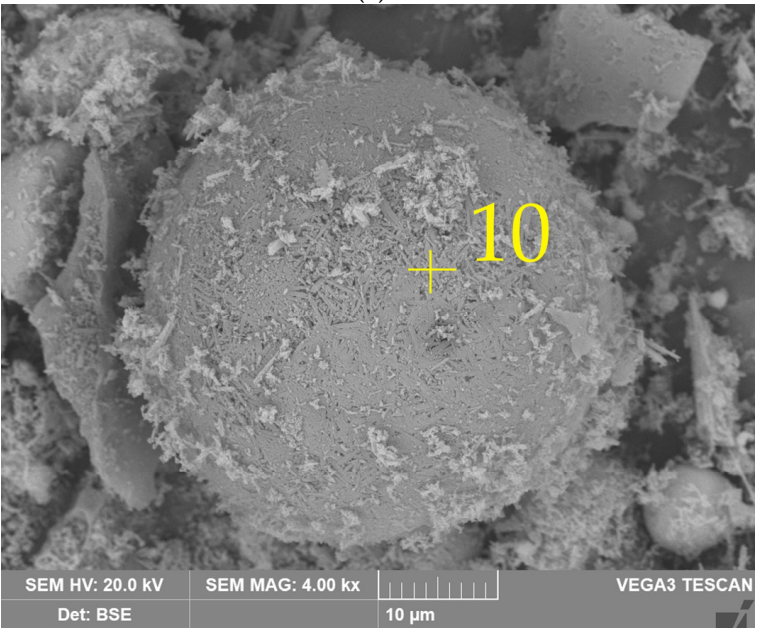

(e)

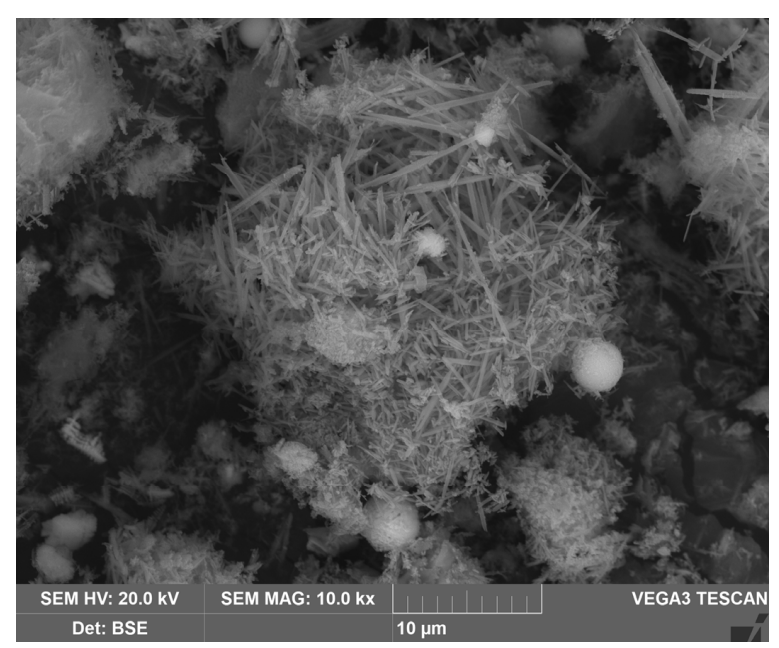

(b)

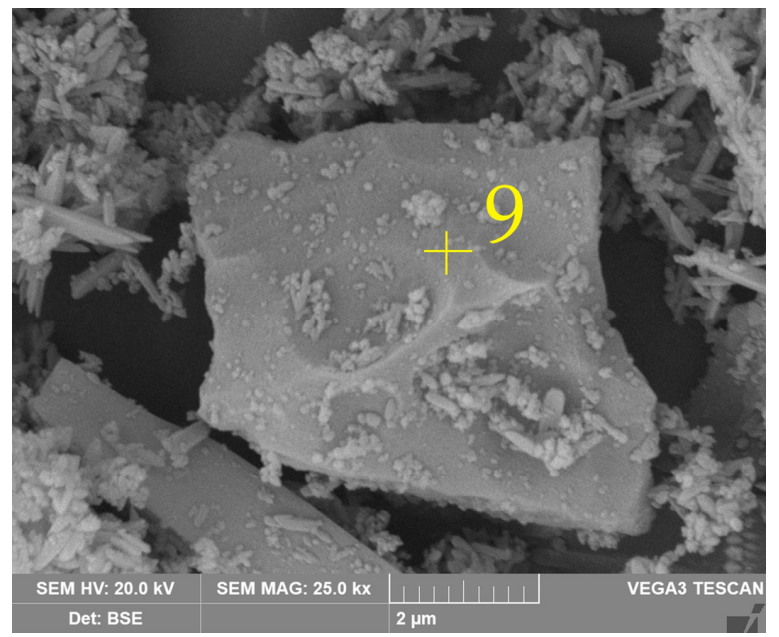

(d)

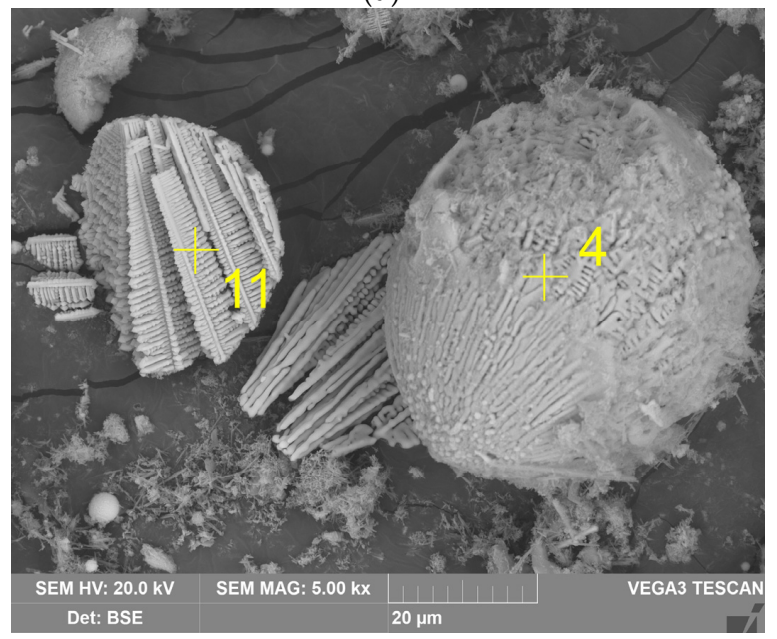

(f)

Figure 11. The SEM images of the solid residue at 5000 magnitude (a) and at 10,000 magnitude (b); the SEM images with the EDX analysis at 2000 magnitude (c); the SEM images with the EDX analysis of quartz particle at 25,000 magnitude (d); mullite particle at 4000 magnitude (e) and magnetite particles at 5000 magnitude (f) (yellow crosses indicate places of SEM-EDX analysis; the elemental composition is shown in Table 6). 
Except for $\mathrm{Al}, \mathrm{Si}$, and $\mathrm{Fe}$, the solid residue contains a high amount of $\mathrm{Ca}$ and $\mathrm{Ti}$ (Table 5), the phases of which are not seen on the XRD pattern (Figure 10). The correlation of $\mathrm{Ca}$ and $\mathrm{Ti}$ with other minor elements was evaluated by SEM-EDX mapping of the surfaces of the particles, as can be seen in Figure 12. Ti was found to be concentrated on the surface of the Al-rich phase, i.e., mullite. Ti mapping is also partially correlated with Ca-rich phases. The association of Ti with the Fe-rich phase, on the contrary, is low. Thus, it can be assumed that $\mathrm{Ti}$ is partially dissolved; then, it is precipitated on the mullite surfaces in the form of insoluble $\mathrm{Na}$ and Ca-containing compounds, as it has a place when diasporic bauxites are leached with highly concentrated alkaline solutions [50]. These Ti compounds can serve as the product layer that inhibits intraparticle diffusion. Therefore, the addition of lime or Fe(II) ions [50] is needed to reduce the Ti inhibition effect. However, mullite spheres (Figure 10e) with low porosity surface remain unleached even after three stages of alkaline leaching (not described in this article), and they have no Ti on the surface. It is possible that the dense packing of mullite particles in these agglomerates reduces their reactivity. Again, the high activation energy confirms that the surface chemical reaction could be the rate-limiting stage of the process. Therefore, high-pressure leaching is necessary for complete $\mathrm{Al}$ extraction from CFA. On the other hand, an increase in temperature will also increase the precipitation rate of DSP, which will lead to large losses of aluminum and alkali.

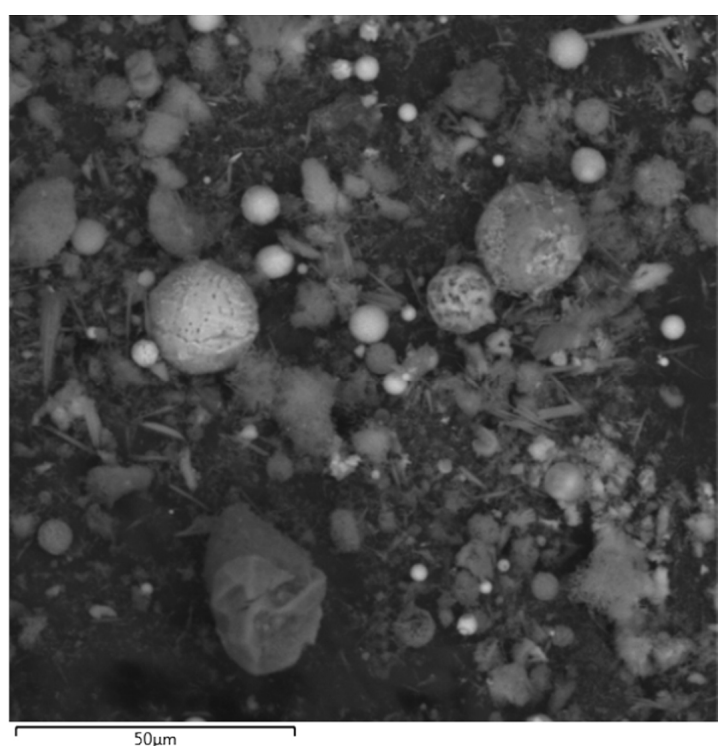

(a)

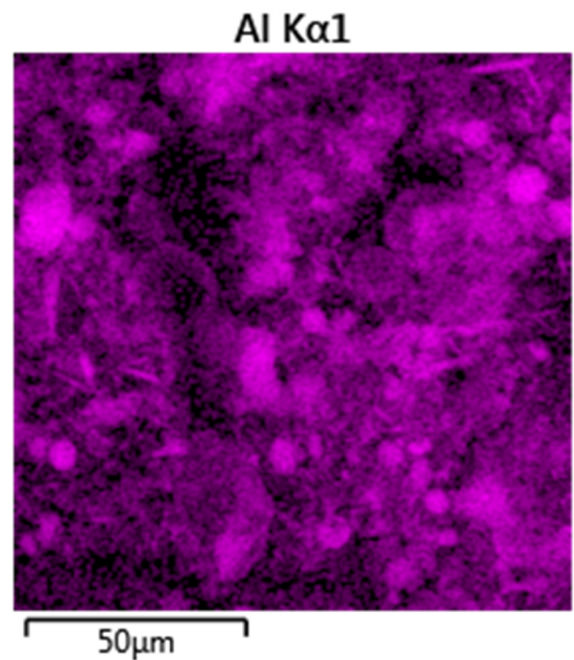

(c)

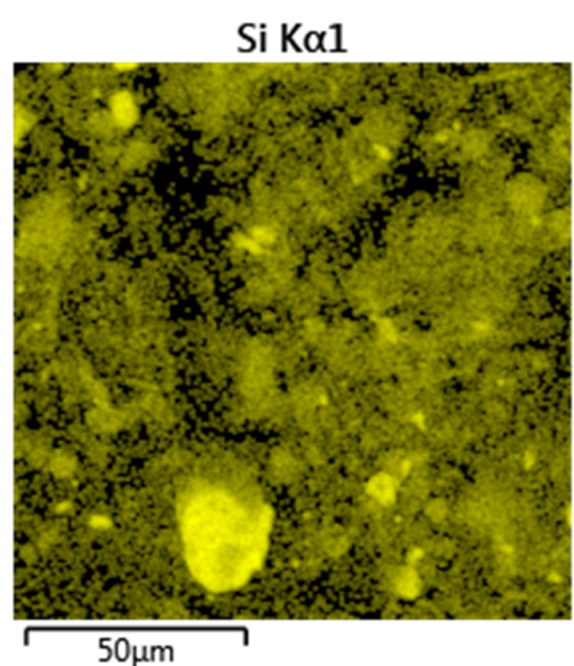

(b)

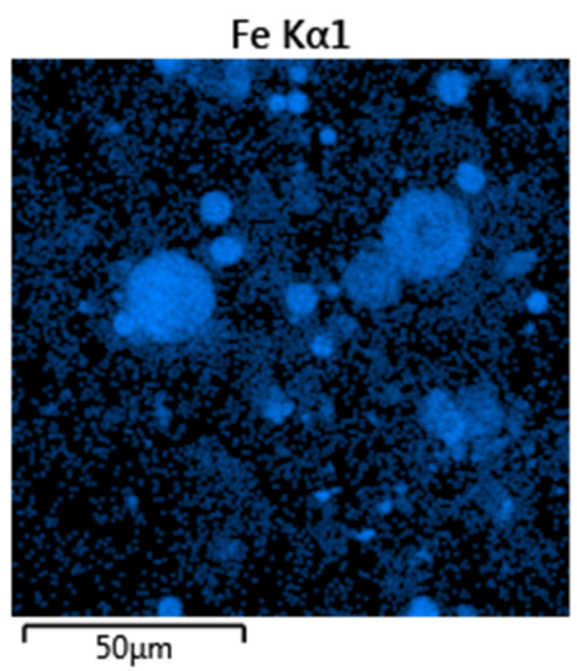

(d)

Figure 12. Cont. 


\section{$\mathrm{Ti} K \alpha 1$}

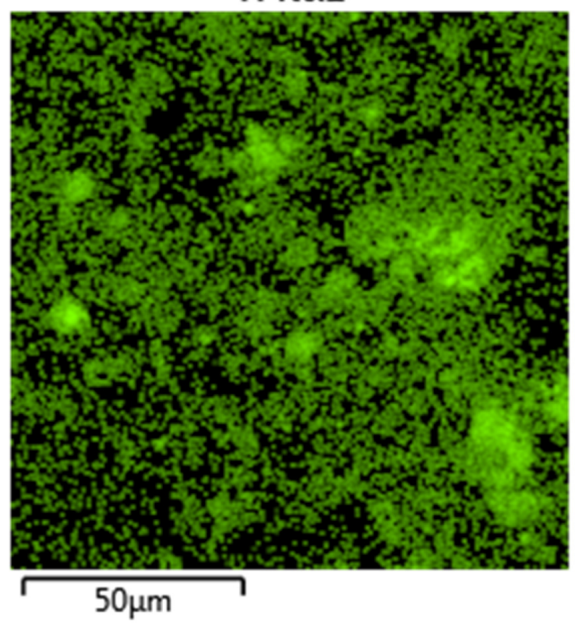

(e)

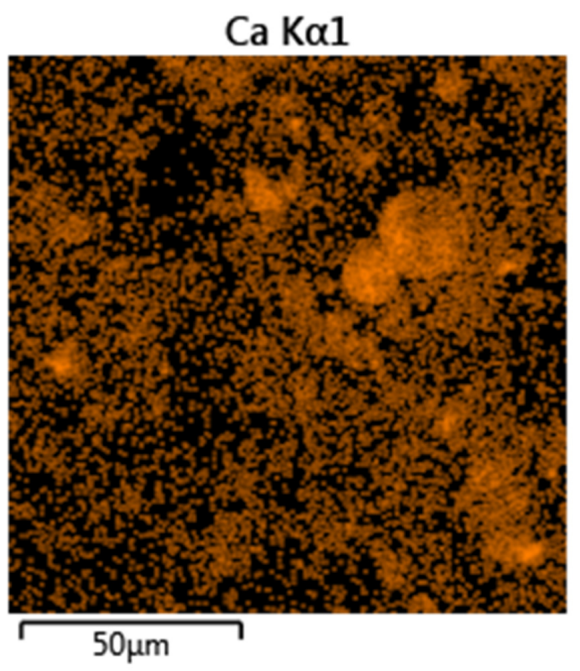

(f)

Figure 12. Mapping of DCFA surface using SEM-EDX analysis: BSE image of the surface (a); mapping of the Si distribution (b); mapping of the $\mathrm{Al}$ distribution (c); mapping of the Fe distribution (d); mapping of the Ti distribution (e); mapping of the Ca distribution (f).

According to the data in Table 7, the DCFA specific surface area does not change after $\mathrm{NaOH}$ leaching. This means that in this case, there is no porous reaction product, and the dissolving of mullite particles leaves the magnetite particles with the same particle size and porosity.

Figure 13 shows the schematic flow chart of the CFA alkaline atmospheric leaching after preliminary desilication and the extraction efficiency of Al and Si on each stage of the process at optimal parameters. As it was shown above, at the desilication stage about 17 wt. \% of $\mathrm{Al}$ was dissolved. To enhance the $\mathrm{Al}$ extraction degree from the CFA, the DSP can be precipitated from the solution obtained at the desilication stage by addition of the DSP seed and stirring $60-120 \mathrm{~min}$ at $100-200{ }^{\circ} \mathrm{C}$. The Al from the DSP can be further extracted by sintering it with soda followed by water or acid leaching [34]. The Si that was extracted at the mullite leaching step can be separated from Al by the stepwise precipitation that will be discussed in our future research.

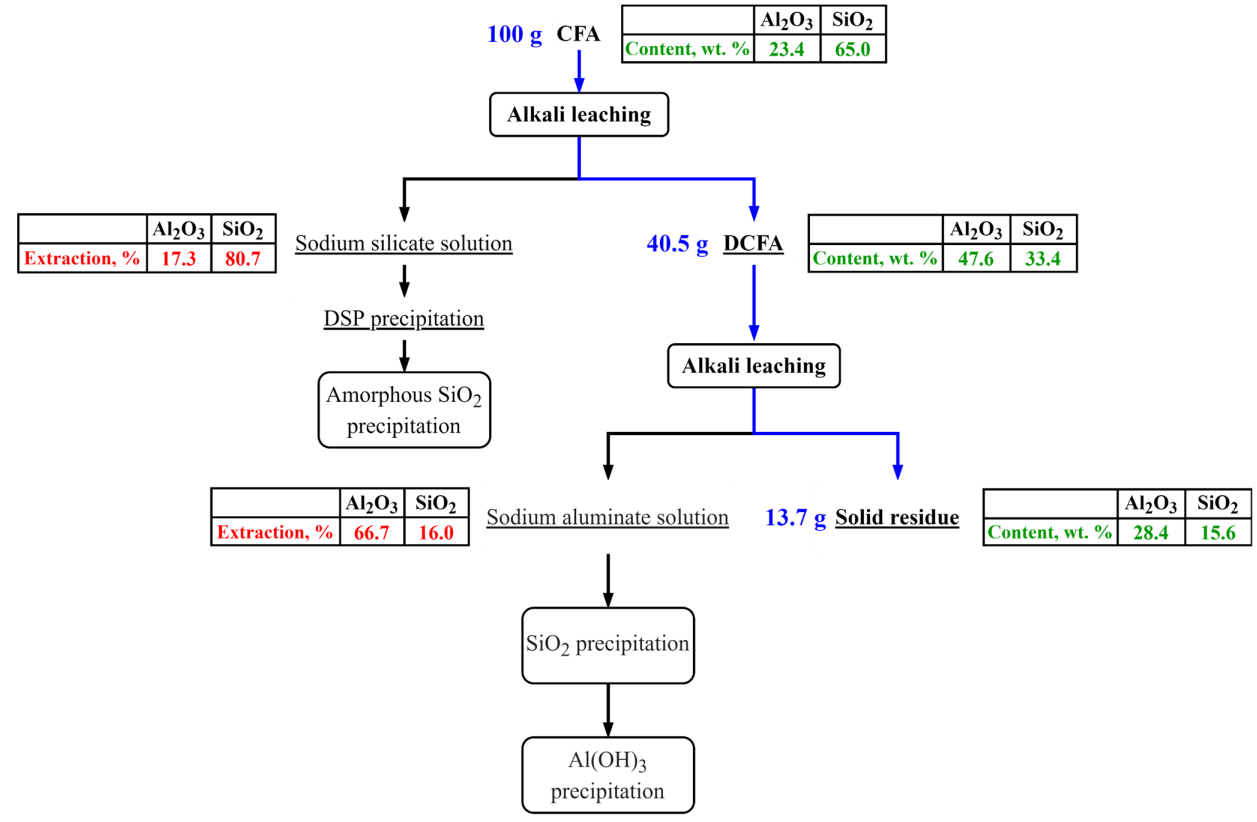

Figure 13. The schematic flow chart of the CFA alkaline atmospheric leaching after preliminary desilication and the extraction efficiency of $\mathrm{Al}$ and $\mathrm{Si}$. 


\section{Conclusions}

This article showed that the atmospheric pressure alkaline leaching of mullite from preliminary desilicated CFA is possible at the optimized parameters. Using the artificial neural network method and shrinking core model, it was established that the leaching time, temperature, and initial concentration of alumina are essential to dissolve more than $80 \%$ of mullite. The main conclusions are as follows:

1. To extract mullite at atmospheric pressure, preliminary desilication at a high L:S ratio is necessary in order to accept DSP formation and expose the surface of mullite particles.

2. According to the response surfaces obtained by the SANN method, at $\mathrm{T}=120^{\circ} \mathrm{C}$, $\mathrm{L}: \mathrm{S}$ ratio $=20, \tau=60 \mathrm{~min}, \mathrm{C}_{\mathrm{Na} 2 \mathrm{O}}=400 \mathrm{~g} \mathrm{~L}^{-1}$, and $\mathrm{C}_{\mathrm{Al} 2 \mathrm{O} 3}{ }^{0}=0 \mathrm{~g} \mathrm{~L}^{-1}$, the $\mathrm{Al}$ extraction degree is $84 \%$. A very low extraction degree is observed at the same parameters but $\mathrm{C}_{\mathrm{Al2O} 3}{ }^{0}=390 \mathrm{~g} \mathrm{~L}^{-1}$. It indicates low solubility of mullite at a given temperature.

3. The kinetics analysis by a shrinking core model (SCM) has showed that the surface chemical reaction controls the leaching process rate at $\mathrm{T}<110{ }^{\circ} \mathrm{C}$, and, at $\mathrm{T}>110^{\circ} \mathrm{C}$ after $15 \mathrm{~min}$ of leaching, the process is limited by diffusion through the product layer, which can be represented by titanium compounds. The apparent $E_{a}$ was $92.0 \mathrm{~kJ} / \mathrm{mol}$.

4. The unleached mullite in the solid residue is represented by individual acicular particles, as well as agglomerates with high alumina content and low porosity surface. The whole extraction efficiency of $\mathrm{Si}$ and $\mathrm{Al}$ after desilication and mullite leaching was more than $97 \%$ and $84 \%$, respectively.

Author Contributions: Conceptualization, A.S., I.L.; methodology, I.L.; validation, A.S., I.L.; formal analysis, A.S., D.V.; investigation, A.S.; resources, D.V., I.L.; data curation, I.L.; writing-original draft preparation, A.S., I.L.; writing-review and editing, A.S., D.V.; visualization, D.V.; supervision, A.S.; project administration, I.L.; funding acquisition, A.S. All authors have read and agreed to the published version of the manuscript.

Funding: This work was funded by State Assignment, grant № 075-03-2021-051/5. The method of Al content analysis in CFA by ICP-OES was funded by a Ministry of Science and Higher Education of the Russian Federation scientific topic № 0137-2019-0023.

Institutional Review Board Statement: Not applicable.

Informed Consent Statement: Not applicable.

Data Availability Statement: The study did not report any data.

Acknowledgments: The authors would like to recognize the assistance provided by Diana Manukovskaya from Tananaev Institute of Chemistry-Subdivision of the Federal Research Centre (Kola Science Centre of the Russian Academy of Sciences) (Apatity, Russia) for English language editing of the article. The authors also express our gratitude to Evgeny Kolesnikov from NUST MISiS (Moscow, Russia) for assistance of the SEM, XRD, and BET analyses of solid samples.

Conflicts of Interest: The authors declare no conflict of interest.

\section{References}

1. Yao, Z.T.; Xia, M.S.; Sarker, P.K.; Chen, T. A review of the alumina recovery from coal fly ash, with a focus in China. Fuel 2013, 120 , 74-85. [CrossRef]

2. Ding, J.; Ma, S.; Shen, S.; Xie, Z.; Zheng, S.; Zhang, Y. Research and industrialization progress of recovering alumina from fly ash: A concise review. Waste Manag. 2017, 60, 375-387. [CrossRef] [PubMed]

3. Wei, C.; Cheng, S.; Zhu, F.; Tan, X.; Li, W.; Zhang, P.; Miao, S. Digesting high-aluminum coal fly ash with concentrated sulfuric acid at high temperatures. Hydrometallurgy 2018, 180, 41-48. [CrossRef]

4. Ma, Z.; Zhang, S.; Zhang, H.; Cheng, F. Novel extraction of valuable metals from circulating fluidized bed-derived high-alumina fly ash by acid-alkali-based alternate method. J. Clean. Prod. 2019, 230, 302-313. [CrossRef]

5. Bai, G.-H.; Teng, W.; Wang, X.-G.; Qin, J.-G.; Xu, P.; Li, P.-C. Alkali desilicated coal fly ash as substitute of bauxite in lime-soda sintering process for aluminum production. Trans. Nonferrous Met. Soc. China 2010, 20, s169-s175. [CrossRef]

6. Bazhin, V.Y.; Beloglazov, I.; Feshchenko, R. Deep conversion and metal content of Russian coals. Eurasian Min. 2016, 2, 28-32. [CrossRef] 
7. Ding, J.; Ma, S.; Xie, Z.; Wang, X.; Zheng, S.; Zhang, Y. Formation mechanism of an undesirable by-product in the mild hydro-chemical process for the extraction of alumina from fly ash and its mitigation. Hydrometallurgy 2019, 186, $292-300$. [CrossRef]

8. Liu, G.; Liu, Y.; Zhang, T. Approaches to improve alumina extraction based on the phase transformation mechanism of recovering alkali and extracting alumina by the calcification-carbonization method. Hydrometallurgy 2019, 189, 105123. [CrossRef]

9. Zong, Y.; Li, F.; Chen, W.; Liu, Z. Extraction of alumina from high-alumina coal ash using an alkaline hydrothermal method. SN Appl. Sci. 2019, 1, 783. [CrossRef]

10. Bai, G.; Qiao, Y.; Shen, B.; Chen, S. Thermal decomposition of coal fly ash by concentrated sulfuric acid and alumina extraction process based on it. Fuel Process. Technol. 2011, 92, 1213-1219. [CrossRef]

11. Rampou, M.; Ndlovu, S.; Shemi, A. Purification of Coal Fly Ash Leach Liquor for Alumina Recovery Using an Integrated Precipitation and Solvent Extraction Process. J. Sustain. Met. 2017, 3, 782-792. [CrossRef]

12. Rui, H.; Zhang, L.; Li, L.; Zhu, L. Solvent extraction of lithium from hydrochloric acid leaching solution of high-alumina coal fly ash. Chem. Phys. Lett. 2021, 771, 138510. [CrossRef]

13. Shemi, A.; Mpana, R.; Ndlovu, S.; van Dyk, L.; Sibanda, V.; Seepe, L. Alternative techniques for extracting alumina from coal fly ash. Miner. Eng. 2012, 34, 30-37. [CrossRef]

14. Kumar, A.; Agrawal, S.; Dhawan, N. Processing of Coal Fly Ash for the Extraction of Alumina Values. J. Sustain. Met. 2020, 6, 294-306. [CrossRef]

15. Gong, B.; Tian, C.; Xiong, Z.; Zhao, Y.; Zhang, J. Mineral changes and trace element releases during extraction of alumina from high aluminum fly ash in Inner Mongolia, China. Int. J. Coal Geol. 2016, 166, 96-107. [CrossRef]

16. Guo, Y.; Li, J.; Yan, K.; Cao, L.; Cheng, F. A prospective process for alumina extraction via the co-treatment of coal fly ash and bauxite red mud: Investigation of the process. Hydrometallurgy 2019, 186, 98-104. [CrossRef]

17. Shemi, A.; Ndlovu, S.; Sibanda, V.; van Dyk, L. Extraction of alumina from coal fly ash using an acid leach-sinter-acid leach technique. Hydrometallurgy 2015, 157, 348-355. [CrossRef]

18. Shi, Y.; Jiang, K.-X.; Zhang, T.-A. Cleaner extraction of alumina from coal fly ash: Baking-electrolysis method. Fuel 2020, 273, 117697. [CrossRef]

19. Sun, L.; Luo, K.; Fan, J.; Lu, H. Experimental study of extracting alumina from coal fly ash using fluidized beds at high temperature. Fuel 2017, 199, 22-27. [CrossRef]

20. Wu, Y.; Xu, P.; Chen, J.; Li, L.; Li, M. Effect of Temperature on Phase and Alumina Extraction Efficiency of the Product from Sintering Coal Fly Ash with Ammonium Sulfate. Chin. J. Chem. Eng. 2014, 22, 1363-1367. [CrossRef]

21. Guo, Y.; Li, Y.; Cheng, F.; Wang, M.; Wang, X. Role of additives in improved thermal activation of coal fly ash for alumina extraction. Fuel Process. Technol. 2013, 110, 114-121. [CrossRef]

22. Liu, D.; Fang, L.; Guo, Y.; Yan, K.; Yao, C.; Cheng, F. Effects of calcium oxide and ferric oxide on the process of alumina extraction of coal fly ash activated by sodium carbonate. Hydrometallurgy 2018, 179, 149-156. [CrossRef]

23. Li, S.; Bo, P.; Kang, L.; Guo, H.; Gao, W.; Qin, S. Activation Pretreatment and Leaching Process of High-Alumina Coal Fly Ash to Extract Lithium and Aluminum. Metals 2020, 10, 893. [CrossRef]

24. Yan, F.; Jiang, J.; Liu, N.; Gao, Y.; Meng, Y.; Li, K.; Chen, X. Green synthesis of mesoporous $\gamma$-Al2O3 from coal fly ash with simultaneous on-site utilization of $\mathrm{CO}_{2}$. J. Hazard. Mater. 2018, 359, 535-543. [CrossRef] [PubMed]

25. Tanvar, H.; Chauhan, S.; Dhawan, N. Extraction of aluminum values from fly ash. Mater. Today Proc. 2018, 5, 17055-17063. [CrossRef]

26. Shoppert, A.A.; Loginova, I.V.; Chaikin, L.I.; Rogozhnikov, D.A. Alkali Fusion-Leaching Method For Comprehensive Processing Of Fly Ash. KnE Mater. Sci. 2017, 2, 89. [CrossRef]

27. Valeev, D.; Shoppert, A.; Mikhailova, A.; Kondratiev, A. Acid and Acid-Alkali Treatment Methods of Al-Chloride Solution Obtained by the Leaching of Coal Fly Ash to Produce Sandy Grade Alumina. Metals 2020, 10, 585. [CrossRef]

28. Wang, P.; Liu, H.; Zheng, F.; Liu, Y.; Kuang, G.; Deng, R.; Li, H. Extraction of Aluminum from Coal Fly Ash Using Pressurized Sulfuric Acid Leaching with Emphasis on Optimization and Mechanism. JOM 2021, 73, 2643-2651. [CrossRef]

29. Wu, Y.; Yang, X.; Li, L.; Wang, Y.; Li, M. Kinetics of extracting alumina by leaching coal fly ash with ammonium hydrogen sulfate solution. Chem. Pap. 2019, 73, 2289-2295. [CrossRef]

30. Tripathy, A.; Behera, B.; Aishvarya, V.; Sheik, A.; Dash, B.; Sarangi, C.; Tripathy, B.; Sanjay, K.; Bhattacharya, I. Sodium fluoride assisted acid leaching of coal fly ash for the extraction of alumina. Miner. Eng. 2018, 131, 140-145. [CrossRef]

31. Zhang, X.; Du, T.; Jia, H. Efficient Activation of Coal Fly Ash for Silica and Alumina Leaches and the Dependence of Pb(II) Removal Capacity on the Crystallization Conditions of Al-MCM-41. Int. J. Mol. Sci. 2021, 22, 6540. [CrossRef]

32. Zhang, J.-B.; Li, S.-P.; Li, H.-Q.; He, M.-M. Acid Activation for Pre-Desilicated High-Alumina Fly Ash. Fuel Process. Technol. 2016, 151, 64-71. [CrossRef]

33. Smith, P. The processing of high silica bauxites-Review of existing and potential processes. Hydrometallurgy 2009, 98, 162-176. [CrossRef]

34. Guo, Y.; Zhao, Z.; Zhao, Q.; Cheng, F. Novel process of alumina extraction from coal fly ash by pre-desilicating-Na2CO3 activation-Acid leaching technique. Hydrometallurgy 2017, 169, 418-425. [CrossRef] 
35. Panek, R.; Wdowin, M.; Franus, W.; Czarna-Juszkiewicz, D.; Stevens, L.; Deng, H.; Liu, J.; Sun, C.; Liu, H.; Snape, C. Fly ash-derived MCM-41 as a low-cost silica support for polyethyleneimine in post-combustion $\mathrm{CO}_{2}$ capture. J. CO2 Util. 2017, 22, 81-90. [CrossRef]

36. Yan, F.; Jiang, J.; Tian, S.; Liu, Z.; Shi, J.; Li, K.; Chen, X.; Xu, Y. A Green and Facile Synthesis of Ordered Mesoporous Nanosilica Using Coal Fly Ash. ACS Sustain. Chem. Eng. 2016, 4, 4654-4661. [CrossRef]

37. Ju, T.; Jiang, J.; Meng, Y.; Yan, F.; Xu, Y.; Gao, Y.; Aihemaiti, A. An Investigation of the Effect of Ultrasonic Waves on the Efficiency of Silicon Extraction from Coal Fly Ash. Ultrason. Sonochem. 2020, 60, 104765. [CrossRef]

38. Czarna-Juszkiewicz, D.; Kunecki, P.; Panek, R.; Madej, J.; Wdowin, M. Impact of Fly Ash Fractionation on the Zeolitization Process. Materials 2020, 13, 1035. [CrossRef]

39. Kunecki, P.; Panek, R.; Wdowin, M.; Bien, T.; Franus, W. Influence of the fly ash fraction after grinding process on the hydrothermal synthesis efficiency of Na-A, Na-P1, Na-X and sodalite zeolite types. Int. J. Coal Sci. Technol. 2020, 8, 291-311. [CrossRef]

40. Ma, Z.; Zhang, X.; Guo, Y.; Cheng, F. Extraction of Valuable Metals and Preparation of Mesoporous Materials from Circulating Fluidized Bed-Derived Fly Ash via an Acid-Alkali-Based Alternate Method. ACS Omega 2020, 5, 31295-31305. [CrossRef]

41. Aphane, M.E.; Doucet, F.J.; Kruger, R.A.; Petrik, L.; Van Der Merwe, E.M. Preparation of Sodium Silicate Solutions and Silica Nanoparticles from South African Coal Fly Ash. Waste Biomass Valorization 2019, 11, 4403-4417. [CrossRef]

42. Liu, C.; Ma, S.; Ding, J.; Luo, Y.; Zheng, S.; Zhang, Y. Kinetics of Decomposition of Mullite and Corundum in Coal Fly Ash under Highly Alkaline Condition. Trans. Nonferrous Met. Soc. China 2019, 29, 868-875. [CrossRef]

43. Ding, J.; Ma, S.; Zheng, S.; Zhang, Y.; Xie, Z.; Shen, S.; Liu, Z. Study of extracting alumina from high-alumina PC fly ash by a hydro-chemical process. Hydrometallurgy 2016, 161, 58-64. [CrossRef]

44. Myerson, A.S. Handbook of Industrial Crystallization; Butterworth-Heinemann: Oxford, UK, 2002; ISBN 978-0-08-053351-3.

45. Loginova, I.V.; Shoppert, A.A.; Chaikin, L.I. Extraction of Rare-Earth Metals during the Systematic Processing of DiasporeBoehmite Bauxites. Metallurgist 2016, 60, 198-203. [CrossRef]

46. Taleb, K.; Markovski, J.; Milosavljević, M.; Marinović-Cincović, M.; Rusmirović, J.; Ristić, M.; Marinković, A. Efficient arsenic removal by cross-linked macroporous polymer impregnated with hydrous iron oxide: Material performance. Chem. Eng. J. 2015, 279, 66-78. [CrossRef]

47. Bialik, M.; Sedin, P.; Theliander, H. Boiling Point Rise Calculations in Sodium Salt Solutions. Ind. Eng. Chem. Res. 2008, 47, 1283-1287. [CrossRef]

48. Levenspiel, O. Chemical Reaction Engineering, 3rd ed.; Wiley: New York, NY, USA, 1999; ISBN 978-0-471-25424-9.

49. Gok, O.; Anderson, C.G.; Cicekli, G.; Cocen, E.I. Leaching kinetics of copper from chalcopyrite concentrate in nitrous-sulfuric acid. Physicochem. Probl. Miner. Process. 2014, 50, 399-413. [CrossRef]

50. Li, X.-B.; Wang, Y.-L.; Zhou, Q.-S.; Qi, T.-G.; Liu, G.-H.; Peng, Z.-H.; Wang, H.-Y. Transformation of hematite in diasporic bauxite during reductive Bayer digestion and recovery of iron. Trans. Nonferrous Met. Soc. China 2017, 27, 2715-2726. [CrossRef] 